Review Article

\title{
Grand Challenges as Educational Innovations in Higher Education: A Scoping Review of the Literature
}

\author{
Lorelli Nowell ${ }^{D},{ }^{1}$ Swati Dhingra, ${ }^{1}$ Kimberley Andrews, ${ }^{1}$ Julia Gospodinov, ${ }^{1}$ Cathy Liu, ${ }^{1}$ \\ and K. Alix Hayden $\mathbb{( i D}^{2}$ \\ ${ }^{1}$ Faculty of Nursing, University of Calgary, Calgary, AB, Canada \\ ${ }^{2}$ Libraries and Cultural Resources, University of Calgary, Calgary, AB, Canada
}

Correspondence should be addressed to Lorelli Nowell; lnowell@ucalgary.ca

Received 5 October 2020; Accepted 20 October 2020; Published 9 November 2020

Academic Editor: Gwo-Jen Hwang

Copyright ( 92020 Lorelli Nowell et al. This is an open access article distributed under the Creative Commons Attribution License, which permits unrestricted use, distribution, and reproduction in any medium, provided the original work is properly cited.

Grand challenges are complex problems that are common to much of society, affect large populations, and may have several possible solutions. Incorporation of grand challenges into higher education courses can facilitate the development of collaborative problem-solving skills while providing relevant and practical opportunities to experience the dynamics involved in real-world work. Although grand challenges are becoming more commonly used in higher education, to date, there has been no synthesis of how grand challenges are incorporated and the learning outcomes of engaging in grand challenge work. In this scoping review, we examined and mapped the state of evidence for the use of grand challenges in higher education. We conducted the review according to the Johanna Briggs Institute methodology for scoping reviews and considered quantitative, qualitative, and mixedmethods studies as well as literature reviews, program descriptions, and opinion papers published in English without limitations on year of publication. We used a data extraction tool to synthesize and present our findings in a tabular form with accompanying narrative summaries. The results reveal a growing global interest in the use of grand challenges in higher education while highlighting a lack of rigorous empirical evidence on the impact on student learning.

\section{Introduction}

Today's complex workplace environments demand higher education institutions to prepare graduates who are ready to tackle society's most pressing challenges. However, presentday education may not adequately prepare students for problem-solving approaches required of our modern workforce. Implementing grand challenges within higher education courses may help prepare students to engage in innovative solutions to complex problems.

\section{Grand Challenges}

The concept of grand challenges was first introduced by a German mathematician in 1900, who established 23 problems to foster dialog among mathematicians, spark the development of the discipline, and focus attention on unresolved issues [1]. Different from general disciplinary problems, grand challenges pose greater demands for coordinated and collaborative efforts [1], because they affect large populations, and cannot be effectively tackled by an individual organization, community, or discipline [2]. Fundamentally, grand challenges are global and common to much of society [1], which implies that their impact goes beyond a single discipline due to their complexity [2], longterm horizon, and wickedness [3]. Given the dynamic nature of grand challenges, it is difficult to develop simple solutions because they can take several years or decades to emerge and their impact may extend to future generations [4]. Grand challenges are often wicked in that they present large-scale common design problems that may have several possible solutions $[2,5]$.

2.1. Societal Grand Challenges. The distinctive feature of societal grand challenges is that they are highly significant 
and potentially solvable [6]. Societal grand challenges are phenomena with global impacts such as environmental and human health [7], global hunger, urban poverty [6], climate change, ageing societies, natural resources depletion, and gender inequality [1]. These phenomena are common to various degrees across the world.

\subsection{Addressing Grand Challenges. Addressing a grand} challenge requires inclusive leadership that actively seeks out the ideas and input of individuals within and outside the team. Including multiple perspectives provides a better understanding of the complex components of the problem and may lead to a contemporary solution. In business, collaboration among multiple team members from different departments is a common practice to produce solutions for product or service innovation [8]. Kania and Kramer [9] argued that "collective impact initiatives depend on a diverse group of stakeholders working together, not by requiring that all participants do the same thing, but by encouraging each participant to undertake the specific set of activities at which it excels in a way that supports and is coordinated with the actions of others" (p. 40). Such an inclusive approach is crucial considering that many of the most pressing global problems involve and impact individuals from multiple locations, professions, and worldviews.

\subsection{Grand Challenges as Pedagogical Innovations.} Developing solutions to grand challenges as a pedagogical approach has resulted in deep learning for students [10]. Researchers found when instructors incorporated grand challenges into courses, it facilitated the development of collaborative problem-solving skills while providing relevant and practical opportunities to experience the dynamics involved in real-world work [11]. In the field of engineering, grand challenge courses have been designed to promote collaborative problem-solving skills where students need to tackle diverse engineering challenges and integrate ideas to generate a final solution which was highlighted as a critical component [12]. Promoting collaborative processes and involving multiple students to address grand challenges provided relevant and practical opportunities to experience the dynamics involved in the real-world work of an engineer [11].

Experiential learning such as grand challenge work that requires hands-on and applied learning opportunities can have a positive and powerful impact on the quality and meaning of learning experiences [13]. There is sound pedagogical evidence for incorporating experiential approaches into higher education courses. Kuh's [14] influential research on high impact practices demonstrated that experiential learning experiences have a significant impact on students' overall academic success. Employers often seek job applicants with leadership, communication, and problemsolving skills that can be developed through well-designed and effective experiential learning opportunities [15]. As well, the emerging field of learning neuroscience supports experiential learning as being key to long-term memory acquisition [16]. As noted by Kolb and Kolb [17], "when a concrete experience is enriched by reflection, given meaning by thinking, and transformed by action, the new experience created becomes richer, broader, and deeper" (p. 309).

Although grand challenges are being more commonly used in higher education and have been implemented in several disciplines, Ferraro et al. [2] argued more research is needed to understand effective teaching strategies for carrying out grand challenge work, developing grand challenge solutions, and evaluating their impact. While there is emerging evidence that suggests engaging with grand challenges results in deep learning for students, the extent of evidence regarding the benefits of incorporating grand challenges into higher education learning opportunities has not yet been established. To date, there has been no synthesis of how grand challenges are incorporated and the learning outcomes of engaging in grand challenge work. The overarching objective of this review was to examine and map the state of evidence for the use of grand challenges in higher education.

\subsection{Review Questions}

(1) In what contexts are grand challenges being used in higher education?

(2) What learning objectives and assignments are used in higher education courses that incorporate grand challenges?

(3) What types of outcomes have been reported in the literature related to the implementation of grand challenges in higher education classrooms?

(4) What are the gaps in evidence for the use of grand challenges in higher education?

\section{Methods}

3.1. Design. Various systematic approaches are available for reviewing published literature. Scoping reviews are a rigorous and methodical approach to examine the extent, range, and nature of research activity in a particular field. This scoping review was conducted in accordance with Joanna Briggs Institute (JBI) methodology for scoping reviews [18] and reported in accordance with the Preferred Reporting Items for Systematic Reviews and Meta-Analysis for Scoping Reviews Extensions for Scoping Reviews (PRISMA-ScR) [19]. This scoping review methodology guided us to broadly examine and comprehensively and systematically map the grand challenge literature, summarize research findings, and identify gaps where further research is required.

3.2. Eligibility Criteria. For the purpose of this review, grand challenges were defined as complex problems that are common to much of society, affect large populations, and may have several possible solutions. Literature was eligible for inclusion if it focused on undergraduate or graduate students and/or instructors engaged in formal higher education settings where the application of grand challenges was integrated with or applied in the teaching and learning 
TABLE 1: Search strategy in ERIC.

\begin{tabular}{|c|c|c|}
\hline \# & Query & Results \\
\hline S1 & $\begin{array}{l}\text { TI ((Grand or global or societ* or world) N1 challenge* }) \text { OR KW ((Grand or global or societ* or world) N1 challenge* }) \text { OR } \\
\text { AB ((Grand or global or societ* or world) N1 challenge* })\end{array}$ & 841 \\
\hline S2 & $\begin{array}{c}\text { TI (challenging N1 (“social problem*”or "global problem*”or “world problem*”))OR KW (challenging N1 (“social } \\
\text { problem*”or"global problem*”or"world problem*”))OR AB (challenging N1 ("social problem*”or"global } \\
\text { problem*"or"world problem*”)) }\end{array}$ & 8 \\
\hline S3 & TI “integrate module*” OR KW “integrate module*”OR AB “integrate module*” & 4 \\
\hline S4 & TI “big idea*”OR KW “big idea*”OR AB “big idea*” & 486 \\
\hline S5 & TI Hackathon* OR KW Hackathon* OR AB Hackathon* & 11 \\
\hline S6 & $\begin{array}{c}\text { DE "Problem Solving" AND (DE "Social Problems" OR DE “Social Change" OR DE “Global Approach" OR DE "Science } \\
\text { and Society" OR DE "World Problems") }\end{array}$ & 1,146 \\
\hline S7 & S1 OR S2 OR S3 OR S4 OR S5 OR S6 & 2,478 \\
\hline S8 & DE “Higher Education” OR DE “Postsecondary Education” OR DE “Universities” or DE “Colleges” & 492,640 \\
\hline S9 & $\begin{array}{l}\text { DE “Graduate Study” OR DE “Postdoctoral Education” OR DE “Doctoral Programs” OR DE “Graduate Students” OR DE } \\
\text { "Masters Programs” }\end{array}$ & 35,506 \\
\hline S10 & DE “Undergraduate Students” OR DE “College Students” OR DE “College Freshmen” OR DE “Undergraduate Study” & 139,647 \\
\hline S11 & DE “College Faculty” OR DE “College Instruction” & 53,752 \\
\hline S12 & DE “Educational Research" OR DE “Professional Education” & 64,232 \\
\hline S13 & $\begin{array}{l}\text { TI (undergraduate* or graduate* or doctoral }{ }^{*} \text { or student* or professor* or instructor* or faculty or "preservice } \\
\text { teacher" "or"pre-service teacher*") OR KW (undergraduate* or graduate* or doctoral*or student* or professor* or } \\
\text { instructor* or faculty or "preservice teacher*"or"pre-service teacher*") OR AB (undergraduate* or graduate* or } \\
\text { doctoral }{ }^{*} \text { or student* or professor* or instructor* or faculty or "preservice teacher*"or "pre-service teacher*") }\end{array}$ & 776,672 \\
\hline S14 & $\begin{array}{c}\text { TI (academic or "higher education" or universit* or college* or postsecondary or post-secondary) OR KW (academic or } \\
\text { "higher education" or universit* or college* or postsecondary or post-secondary) OR AB (academic or "higher education" } \\
\text { or universit* or college* or postsecondary or post-secondary) }\end{array}$ & 471,711 \\
\hline S15 & S8 OR S9 OR S10 OR S11 OR S12 OR S13 OR S14 & $1,033,468$ \\
\hline S16 & S7 AND S15 & 1,696 \\
\hline S17 & $\begin{array}{l}\quad \text { S7 AND S15 } \\
\text { Narrow by Language: English } \\
\text { Excluded dissertations, books }\end{array}$ & 1,538 \\
\hline
\end{tabular}

process to identify potential solutions. Primary research studies including qualitative, quantitative, and mixedmethods studies were eligible. In addition, literature reviews as well as text and opinion papers that met the inclusion criteria were considered. Only studies written in English were included due to difficulty in obtaining foreign language studies and the lack of language capabilities of the team.

We excluded dissertations, books, book chapters, book reviews, websites, and conference abstracts that did not include a full-text paper. Literature studies that focused on K-12 students or educators were also excluded. Literature studies that included grand challenges in higher education teaching and learning but did not attempt to identify a solution were also excluded.

3.3. Information Sources and Search Strategy. We followed the JBI scoping review method which includes a three-step search strategy. First, an experienced health sciences librarian conducted an exploratory search of the truncated phrase "global challenge*" in a multidatabase search on the EBSCO platform. The four databases searched simultaneously included: Academic Search Complete, CINAHL, ERIC, and GeoRef. The exploratory search helped to identify key studies, relevant keywords in the titles and abstracts, as well as the subject headings. This analysis informed the development of a draft search in ERIC, the prime education database. The draft search was piloted to ensure that all key studies were retrieved. The second step included finalizing the ERIC search strategy (Table 1), which was then adapted for all other databases, taking into account database syntax and thesaurus. In order to conduct a thorough investigation into grand challenges in postsecondary environments, both disciplinary and interdisciplinary databases were searched from inception until May 3, 2020. Disciplinary databases searched include the following:

(i) EBSCO databases: Business Source Complete, CINAHL Plus with Full Text, Education Research Complete, Environment Complete, ERIC, GeoRef, SocINDEX with Full Text, and Social Work Abstracts

(ii) OVID databases: MEDLINE, Embase, and APA PsycINFO

(iii) ProQuest databases: Sociological Abstracts

(iv) Other databases: Compendex and IEEE Xplore

Interdisciplinary databases searched included Academic Search Complete (EBSCO), Scopus, and Web of Science. Relevant sources of unpublished studies and grey literature were searched including American Educational Research Association, Annual Conference on Higher Education Pedagogy, Association for the Study of Higher Education, Canadian Society for the Study of Higher Education, EuroSoTL, Higher Education Research and Development Society of Australasia, International Society for the Scholarship of Teaching and 
Learning, Lilly National Conference on College and University Teaching and Learning, Midwest SoTL Conference, Society of Teaching and Learning in Higher Education, SoTL Commons, SoTL in the South Conference, and Symposium on Scholarship of Teaching and Learning. Finally, the third step involved snowball searching, where the references and cited bys of included studies were screened for additional studies.

3.4. Source of Evidence Selection. Following the search, all identified records were exported and uploaded into Covidence (Covidence, Melbourne, Australia) and were then deduplicated using Covidence's deduplication function. We conducted pilot testing on a random sample of 25 titles/ abstracts and the team screened this sample using our predefined inclusion criteria. We discussed any discrepancies and clarified the inclusion and exclusion criteria to ensure consistency across the team. Once we achieved greater than $75 \%$ agreement across team members, all titles and abstracts were screened by two independent reviewers for assessment against the inclusion criteria. A third reviewer resolved conflicts in the title and abstract review. Literature studies that met the inclusion criteria were retrieved in full and assessed in detail by two independent reviewers against the inclusion criteria. Full-text studies that did not meet the inclusion criteria were excluded, and reasons for exclusion were provided. Disagreements that arose between two reviewers were resolved by a third reviewer.

3.5. Data Extraction. We used a descriptive analytical method to extract contextual information from included literature. The review team developed a data extraction tool that we continually updated as new key findings emerged. We piloted the data extraction form on a random sample of 10 included articles to ensure consistency amongst the review team. Each included article was extracted by one team member using a standardized data extraction tool and was then verified by a second reviewer. Weekly meetings were held amongst team members to determine consistency in approach to data extraction. The data extracted included year, authors, publication title, journal, country, institutional affiliation, discipline, context/population, course description, course objectives, grand challenge topic, course assignments, study characteristics, and key findings in relation to the review questions. Any disagreements that arose between the reviewers were resolved through discussion and/ or a third reviewer.

3.6. Data Synthesis. Our synthesis included quantitative analysis using a simple numerical count and qualitative analysis using narrative synthesis in alignment with the objective of this scoping review. Article characteristics, grand challenge courses, and studies related to grand challenges in higher education were summarized in table formats. Narrative summaries were also conducted to add depth to the synthesis.

\section{Results}

After screening 8945 citations and 558 full-text papers, 55 papers met the inclusion criteria and were included in this scoping review $(n=55)$. The flow of data through our review is depicted in Figure 1.

Table 2 displays the characteristics of the literature. The majority of literature came from the United States $(n=40$, $72.7 \%$ ) followed by the United Kingdom ( $n=5,9.1 \%)$. Prior to 2010 , there were only 4 articles published on the use of grand challenges in higher education; however, the numbers have been climbing since, with 10 articles (18.2\%) published in 2019 alone. The majority of literature focused on multidisciplinary teams of higher education students $(n=26$, $47.3 \%)$, followed by engineering students alone $(n=18$, $32.7 \%)$. Most of the grand challenge literature focused on undergraduate students $(n=36,65.5 \%)$ followed by a mix of both undergraduate and graduate students $(n=10,18.2 \%)$, then graduate students $(n=9,16.4 \%)$. Almost every article included a description of a grand challenge course $(n=54$, $98.1 \%$ ), while only 25 articles (45.5\%) included program evaluation or study data.

Multiple categories of grand challenges were addressed in the literature, the majority of which discussed sustainability issues and food and water insecurity. The topic of environmental sustainability encompassed a variety of challenges from sustainable agricultural practices to environmental health risks, such as soil erosion [20], creating sustainable energy required for developing affordable renewable energy sources, such as solar power [21]. For instance, Heinricher and colleagues [22] described a grand challenge that explored how to power up the world where the focus was on designing future energy-efficient homes and vehicles, such as green roofs and hydrogen cars. Other projects aimed at mitigating climate change through pollution sensors or carbon dioxide sequestration [23]. However, some of the major challenges in developing countries include food and water insecurity, and higher education students sought to combat these issues through the reduction of food waste and river cleaning robots [22, 23]. In addition, world health grand challenges encompassed a wide variety of topics from advancing health informatics to engineering better medicines and improving resource allocation between hospitals $[21,24]$. Some developing countries struggled with mosquito-borne illnesses, such as malaria, and therefore, students were given the opportunity to develop solutions through the use of drones at California State University [25]. Other than preventing health risks, grand challenges also focused on improving urban infrastructure through sustainable cities and communities as well as strived to attain world peace through the prevention of nuclear terror and mitigating global violence [21].

Table 3 displays the summary of the grand challenge courses described in the literature. More than half of the courses $(n=28,51.8 \%)$ included multidisciplinary (or interdisciplinary) learning as their primary course objective. Encouraging students to think and plan collaboratively, being part of an interdisciplinary team, along with the promotion of interdisciplinary knowledge, was recognized 


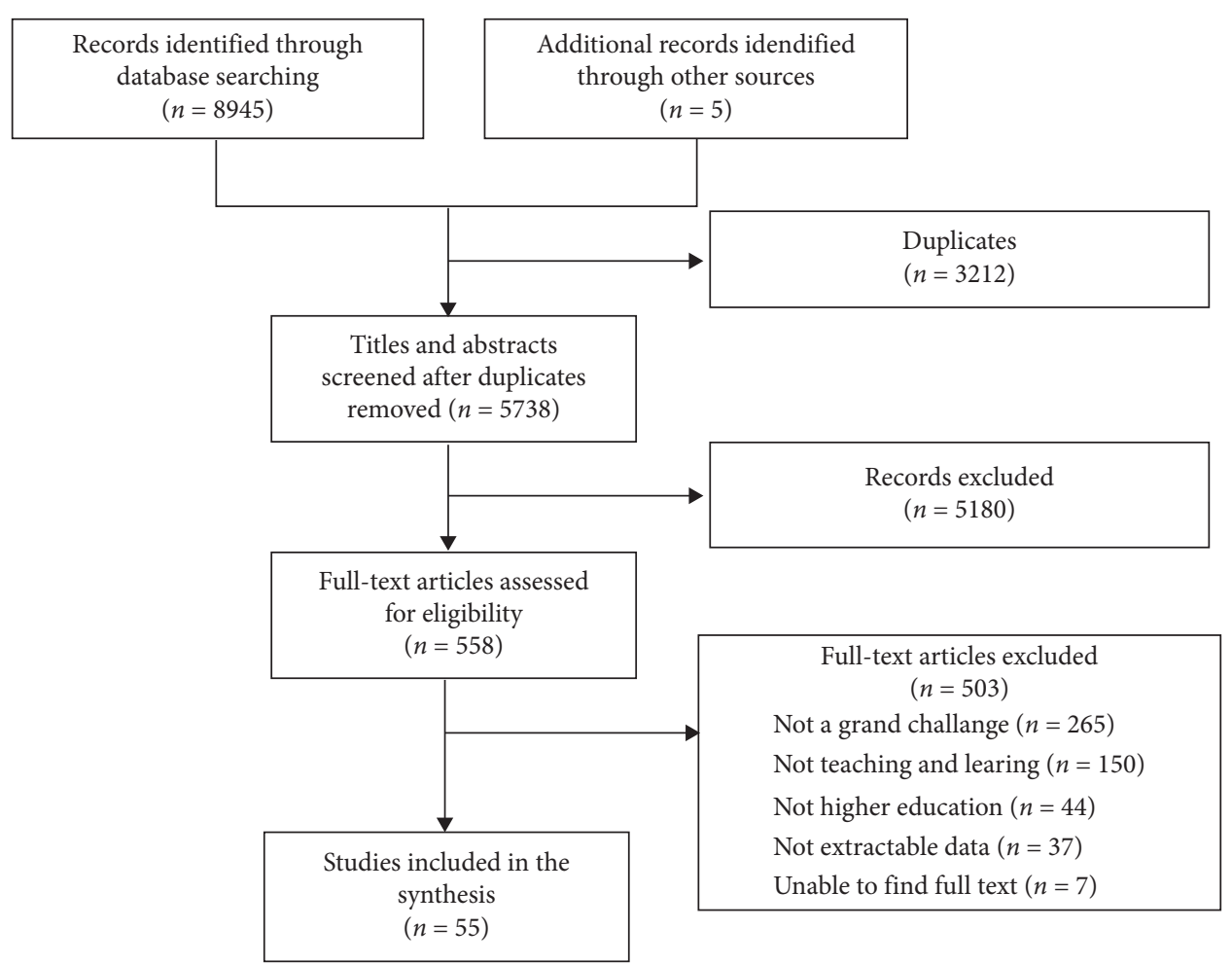

FIgURE 1: PRISMA flow diagram.

as a consistent objective in the courses. Many of the courses ( $n=16,29.6 \%)$ mentioned preparing students to develop innovative solutions to global problems while promoting the concept of sustainability as their major course objective $[26,46]$. Enhancing the problem-solving skills of the students with evidence-based learning concepts was recognized as another common course objective $(n=11,16.6 \%)$ in the literature discussed. This included an improved ability to identify and understand the problem, work and plan around the available resources, and eventually develop viable solutions.

More than half of the articles $(n=28,51.8 \%)$ mentioned some type of student professional development as a common course learning objective. Equipping the students with enhanced professional skills and promoting their career readiness was identified as a major aim. Improved communication skills [39], leadership [49], teamwork [67], and superior critical and strategic thinking abilities [22, 43] were the common listed professional skills in the course objectives. Furthermore, refining the systems and entrepreneurial thinking of students [55] to make them more competent and competitive globally was listed as another common course objective. A few courses mentioned improved subject knowledge and modifications in the educational curriculum as their course learning objective [62].

Table 4 displays the summary of the grand challenge course assessments used in the grand challenge courses. The majority of courses included the use of design thinking projects $(n=48,88.9 \%)$ and presentations $(n=26,48.1 \%)$ as course assessments. Design thinking projects included problem-solving to propose creative solutions. Presentations took place within a course, at conferences, and as part of hackathons or competitions allowing students to demonstrate their knowledge to peers, students, instructors, and stakeholders. A few courses also mentioned the use of essays or reports $(n=13,24 \%)$ and active discussions $(n=11$, $20.3 \%)$ as course assessments. These assessment tools promote the development of transferable professional skills among students including verbal and written communication, leadership, critical thinking, and adaptability.

Table 5 displays an overview of the studies on the use of grand challenges in higher education classrooms. Students perceptions, opinions, and preferences in relation to grand challenge courses were most commonly explored $(n=12$, $48 \%)[25,28,39,45,51,57,61,63,66-68,72]$. Eight studies (32\%) aimed to assess students learning and knowledge development from participation in a grand challenge course $[25,28,39,40,43,62,64,66]$. Skills development was explored in six studies (24\%) [35, 44, 59, 61, 63, 67] while five studies $(n=20 \%)$ focused on evaluating the grand challenge courses themselves $[20,24,30,38,67]$. Only two studies $(8 \%)$ focused on evaluating outputs of the grand challenge course and the impacts they may have on problem-solving attempts $[31,36]$.

Of the 25 studies identified in this review, the majority ( $n=10,40 \%$ ) were mixed-methods studies most commonly using surveys, focus groups, and interviews. Eight studies used qualitative methods only including focus groups, interviews, and reflective assignments (32\%), and six used quantitative surveys (24\%). One study included data on students' perceptions of a course without indicating how data were collected [45]. 
TABLE 2: Literature characteristics.

\begin{tabular}{|c|c|c|c|}
\hline Characteristic & & $n$ & $\%$ \\
\hline \multicolumn{4}{|l|}{ Country } \\
\hline & USA & 40 & 72.7 \\
\hline & United Kingdom & 5 & 9.1 \\
\hline & Australia & 4 & 7.3 \\
\hline & Netherlands & 3 & 5.5 \\
\hline & Brazil & 2 & 3.6 \\
\hline & Canada & 2 & 3.6 \\
\hline & Sweden & 2 & 3.6 \\
\hline & China & 1 & 1.8 \\
\hline & Denmark & 1 & 1.8 \\
\hline & Italy & 1 & 1.8 \\
\hline & Luxembourg & 1 & 1.8 \\
\hline & Singapore & 1 & 1.8 \\
\hline & Switzerland & 1 & 1.8 \\
\hline & Tanzania & 1 & 1.8 \\
\hline \multicolumn{4}{|l|}{ Year } \\
\hline & Pre 2010 & 4 & 7.3 \\
\hline & 2010 & 3 & 5.5 \\
\hline & 2011 & 3 & 5.5 \\
\hline & 2012 & 1 & 1.8 \\
\hline & 2013 & 4 & 7.3 \\
\hline & 2014 & 3 & 5.5 \\
\hline & 2015 & 3 & 5.5 \\
\hline & 2016 & 7 & 12.7 \\
\hline & 2017 & 7 & 12.7 \\
\hline & 2018 & 9 & 16.4 \\
\hline & 2019 & 10 & 18.2 \\
\hline & 2020 & 1 & 1.8 \\
\hline \multicolumn{4}{|l|}{ Discipline } \\
\hline & Multidisciplinary & 26 & 47.3 \\
\hline & Engineering & 18 & 32.7 \\
\hline & Chemistry & 2 & 3.6 \\
\hline & Social Work & 2 & 3.6 \\
\hline & Biology & 1 & 1.8 \\
\hline & Biotechnology & 1 & 1.8 \\
\hline & Business & 1 & 1.8 \\
\hline & Geoscience & 1 & 1.8 \\
\hline & Global Health & 1 & 1.8 \\
\hline & Political Science & 1 & 1.8 \\
\hline & Social Science & 1 & 1.8 \\
\hline \multicolumn{4}{|c|}{ Grand Challenge Topics } \\
\hline & Environmental Sustainability & 26 & 47.3 \\
\hline & Sustainable Energy & 18 & 32.7 \\
\hline & Climate Change/Global Warming & 16 & 29.1 \\
\hline & Food Insecurity & 16 & 29.1 \\
\hline & Water Insecurity & 16 & 29.1 \\
\hline & World Health & 15 & 27.3 \\
\hline & Sustainable Cities and Communities & 8 & 14.5 \\
\hline & World Peace & 8 & 14.5 \\
\hline & Poverty & 7 & 12.7 \\
\hline & Waste Management & 6 & 10.9 \\
\hline & Quality Education & 5 & 9.1 \\
\hline & Housing Crisis/Homelessness & 4 & 7.3 \\
\hline & Improving nutrition & 4 & 7.3 \\
\hline & Political Participation/Social Justice & 4 & 7.3 \\
\hline & Natural Disasters & 4 & 7.3 \\
\hline & Sustainable Transportation & 4 & 7.3 \\
\hline & Increasing Exercise/ Obesity & 3 & 5.5 \\
\hline & Sanitation in developing countries & 3 & 5.5 \\
\hline & Population Growth/Immigration & 2 & 3.6 \\
\hline
\end{tabular}


TABle 2: Continued.

\begin{tabular}{|c|c|c|c|}
\hline Characteristic & & $n$ & $\%$ \\
\hline & Family Violence & 1 & 1.8 \\
\hline & Gender Inequality & 1 & 1.8 \\
\hline & Reducing Drunk Driving & 1 & 1.8 \\
\hline & Refugee Crisis & 1 & 1.8 \\
\hline \multicolumn{4}{|l|}{ Students } \\
\hline & Undergraduate students & 36 & 65.5 \\
\hline & Undergraduate and Graduate Students & 10 & 18.2 \\
\hline & Graduate Students (Masters and $\mathrm{PhD}$ ) & 9 & 16.4 \\
\hline \multicolumn{4}{|c|}{ Types of literature } \\
\hline & Course descriptions & 54 & 98.1 \\
\hline & Studies & 25 & 45.5 \\
\hline & Quantitative studies & 6 & 24 \\
\hline & Qualitative studies & 8 & 32 \\
\hline & Mixed methods studies & 10 & 40 \\
\hline & Unclear & 1 & 4 \\
\hline
\end{tabular}

Country: some literature had more than one country affiliation. Grand challenge topics: some literature looked at multiple grand challenge topics. Types of literature: some literature included both course descriptions and studies.

The authors reported on four main outcomes: (1) course satisfaction, (2) perceptions of the design thinking process, (3) perceptions of interdisciplinary group work, and (4) skill and knowledge development. In general, students were satisfied with grand challenge courses, course material, and course delivery $[24,25,28,45,64,67,68]$. The process of working on design thinking projects focused on broad ideas that could be tailored to individual interests aimed at proposing innovative solutions and providing relevant and valuable real-world learning experience for many students [20, 28, 30, 31 , 36, 40, 44, 45, 51, 59, 61, 62, 66-68]. However, some challenges to integrating design thinking projects were noted. Some students felt deficient in design thinking skills and wanted better preparation in design skills [30, 39]. Other students struggled with ambiguous learning objectives, unclear structure, face pace, and lack of concrete solutions [20, 24].

A number of authors reported on perceptions of interdisciplinary teamwork $(n=10,40 \%)$. In general, students appreciated the interdisciplinary team collaboration $[28,30]$. One study reported that students with positive attitudes towards group work showed greater learning gains throughout the course [43]. In other studies, students noted that interdisciplinary learning helped prepare them for the real world of work and collaboration while offering valuable new perspectives, ideas, and knowledge to develop successful solutions to grand challenges $[31,63]$. In another study that reported on instructor perceptions, the teaching faculty found interdisciplinary team-teaching rewarding and felt that it enriched the class, amplified each other's teaching abilities, and supported professional skills development related to teaching and learning [30]. However, teamwork was not without its challenges. Gillet [38] noted that some teams were challenged with managing schedules or personal conflicts, while Gosselin and colleagues [39] reported that the multidisciplinary aspect created challenges in achieving course learning goals.

The authors also reported on students' knowledge and skills development. Increased content knowledge was discussed in six studies [25, 28, 30, 66-68], while others discussed how students gained a more holistic and systemic understanding of grand challenge topics [35, 57, 63, 67, 68]. Although an increase in student self-confidence and competence was observed in three studies [44, 61, 67], students in another study noted, due to the interdisciplinary nature of the learning, they did not perceive they gained specialized knowledge in their main fields of study [57].

Although quality appraisal is not conducted as part of scoping review methodology $[18,19]$, there are some important issues related to study quality that require further consideration. First, the diversity of methods, study designs, and reporting mechanisms made the identification of meaningful comparisons across the included studies difficult. Some studies did not include clear objectives and/or clear descriptions of data collection and analysis methods. The quantitative studies consisted only of cross-sectional descriptive surveys with the majority applying nonvalidated questionnaires that included very little methodological detail. The lack of description of the study details reduced our ability to generate an in-depth understanding of the impact of grand challenges in the higher education classroom. Overall, the generalizability of the studies included is limited.

\section{Discussion}

We undertook an extensive review of the grand challenge literature in higher education from inception to 2020. To the best of our knowledge, this is the first scoping review exploring the current state of the use of grand challenges as pedagogical innovations in higher education. A detailed review of 55 eligible articles revealed the contexts in which grand challenges are being used, common learning objectives and assignments used in grand challenge course work, outcomes related to the implementation of grand challenges in higher education classrooms, and gaps in the evidence to date. The results reveal a growing global interest in grand challenges in higher education while highlighting a lack of rigorous empirical evidence on the impact on student learning. 
TABLE 3: Summary of grand challenge courses.

\begin{tabular}{|c|c|c|c|c|c|}
\hline $\begin{array}{l}\text { First author } \\
\text { (year) }\end{array}$ & Country and institution & Discipline & Students & $\begin{array}{c}\text { Course learning } \\
\text { objectives }\end{array}$ & Course assessments \\
\hline $\begin{array}{l}\text { Apelian } \\
(2015)[26]\end{array}$ & $\begin{array}{c}\text { USA, Worcester } \\
\text { Polytechnic Institute }\end{array}$ & Engineering & $\begin{array}{c}\text { First-year } \\
\text { undergraduate } \\
\text { engineering students }\end{array}$ & $\begin{array}{c}\text { To learn the concept of } \\
\text { sustainable } \\
\text { development, climate } \\
\text { change, energy sources, } \\
\text { food and water issues, } \\
\text { housing, health, and } \\
\text { transportation } \\
\text { concerns } \\
\text { To approach these } \\
\text { issues proactively and } \\
\text { develop ecologically } \\
\text { sound solutions } \\
\text { To practice all aspects } \\
\text { of college writing and } \\
\text { project development } \\
\text { To learn the importance } \\
\text { of engaging different } \\
\text { disciplinary } \\
\text { perspectives } \\
\text { To learn to formulate } \\
\text { researchable questions } \\
\text { based on multiple } \\
\text { sources } \\
\text { To participate in } \\
\text { classroom debates and } \\
\text { discussions on complex } \\
\text { issues of sustainable } \\
\text { development and } \\
\text { contribute to teamwork }\end{array}$ & $\begin{array}{c}\text { Essays } \\
\text { Active discussions } \\
\text { Design thinking } \\
\text { project } \\
\text { Presentation to a } \\
\text { public forum in the } \\
\text { form of posters and } \\
\text { 4-minute video clips } \\
\text { of the value } \\
\text { proposition of their } \\
\text { proposed solutions }\end{array}$ \\
\hline $\begin{array}{l}\text { Becerik- } \\
\text { Gerber } \\
(2018) \text { [27] }\end{array}$ & $\begin{array}{l}\text { USA, University of } \\
\text { Southern California }\end{array}$ & $\begin{array}{l}\text { Arts, Business, } \\
\text { Cinematic Arts, } \\
\text { Computer Science, } \\
\text { Communication, } \\
\text { Engineering, } \\
\text { Journalism, and } \\
\text { Medicine }\end{array}$ & $\begin{array}{l}26 \text { students } \\
\text { representing } 14 \\
\text { disciplines }\end{array}$ & $\begin{array}{l}\text { To learn how to design } \\
\text { products, services, and } \\
\text { technologies with a } \\
\text { human-centered } \\
\text { approach to help solve } \\
\text { the needs of people in } \\
\text { the midst of global } \\
\text { crises } \\
\text { To learn about the } \\
\text { process of product } \\
\text { innovation, } \\
\text { prototyping, } \\
\text { fabrication, and } \\
\text { building sustainable } \\
\text { business models }\end{array}$ & $\begin{array}{l}\text { Design thinking } \\
\text { project }\end{array}$ \\
\hline
\end{tabular}


TABle 3: Continued.

\begin{tabular}{|c|c|c|c|c|c|}
\hline $\begin{array}{l}\text { First author } \\
\text { (year) }\end{array}$ & Country and institution & Discipline & Students & $\begin{array}{c}\text { Course learning } \\
\text { objectives }\end{array}$ & Course assessments \\
\hline $\begin{array}{l}\text { Berger } \\
(2013)[28]\end{array}$ & USA, Simmons College & $\begin{array}{l}\text { Biology, Chemistry, } \\
\text { Economics, Education, } \\
\text { English, Management, } \\
\text { Math, Nursing, } \\
\text { Nutrition, Physical } \\
\text { Therapy, Political } \\
\text { Science, Public Health, } \\
\text { Social Work, and } \\
\text { Sociology }\end{array}$ & $\begin{array}{l}\text { Sophomores from a } \\
\text { private women's } \\
\text { liberal arts } \\
\text { institution }\end{array}$ & $\begin{array}{l}\text { To grasp key concepts, } \\
\text { principles, and theories } \\
\text { relating to the } \\
\text { complexities } \\
\text { surrounding food } \\
\text { To understand the } \\
\text { critical social issues } \\
\text { such as food insecurity, } \\
\text { sustainability, and } \\
\text { social justice } \\
\text { To understand the } \\
\text { critical technical issues } \\
\text { such as food safety, } \\
\text { production, and } \\
\text { distribution } \\
\text { To evaluate available } \\
\text { information in order to } \\
\text { target and define a } \\
\text { specific issue } \\
\text { To address a specific } \\
\text { global issue related to } \\
\text { food and design and } \\
\text { develop a local solution } \\
\text { To become more } \\
\text { empowered to take the } \\
\text { lead in learning and } \\
\text { become better at risk- } \\
\text { taking in learning } \\
\text { environments } \\
\text { To work effectively in a } \\
\text { team }\end{array}$ & $\begin{array}{l}\text { Group discussion } \\
\text { Presentation } \\
\text { Pretest-posttest } \\
\text { Self-reflection } \\
\text { Journal reflection }\end{array}$ \\
\hline $\begin{array}{l}\text { Bernal } \\
(2013)\end{array}$ & $\begin{array}{l}\text { USA, Rose-Hulman } \\
\text { Institute of Technology }\end{array}$ & $\begin{array}{l}\text { Engineering and } \\
\text { Science }\end{array}$ & $\begin{array}{l}\text { Undergraduate } \\
\text { Engineering and } \\
\text { Science students }\end{array}$ & $\begin{array}{l}\text { To develop feasible } \\
\text { concepts for solar } \\
\text { energy collection } \\
\text { To develop a problem } \\
\text { statement and report } \\
\text { findings } \\
\text { To conduct competitive } \\
\text { benchmarking to } \\
\text { determine how their } \\
\text { alternatives fair in } \\
\text { response to current } \\
\text { products } \\
\text { To build a prototype } \\
\text { and analyze results }\end{array}$ & $\begin{array}{c}\text { Oral exams } \\
\text { Presentation } \\
\text { Peer evaluation } \\
\text { Design thinking } \\
\text { project }\end{array}$ \\
\hline $\begin{array}{l}\text { Brewer } \\
(1993) \text { [29] }\end{array}$ & $\begin{array}{l}\text { USA, University of } \\
\text { California }\end{array}$ & Biology & Biology students & $\begin{array}{l}\text { To develop a model for } \\
\text { the global carbon cycle } \\
\text { To develop an outline } \\
\text { for human implications } \\
\text { of global climate } \\
\text { change }\end{array}$ & $\begin{array}{l}\text { Presentations } \\
\text { Group discussions } \\
\text { Design thinking } \\
\text { project }\end{array}$ \\
\hline
\end{tabular}


Table 3: Continued.

\begin{tabular}{|c|c|c|c|c|c|}
\hline $\begin{array}{l}\text { First author } \\
\text { (year) }\end{array}$ & Country and institution & Discipline & Students & $\begin{array}{c}\text { Course learning } \\
\text { objectives }\end{array}$ & Course assessments \\
\hline $\begin{array}{l}\text { Cohen } \\
(2009) \text { [30] }\end{array}$ & $\begin{array}{c}\text { USA, Eugene Lang } \\
\text { College of Liberal Arts at } \\
\text { The New School }\end{array}$ & $\begin{array}{l}\text { Environmental Studies, } \\
\text { Design and Liberal Arts }\end{array}$ & $\begin{array}{l}\text { Undergraduate } \\
\text { students }\end{array}$ & $\begin{array}{l}\text { To provide students } \\
\text { with the knowledge of } \\
\text { systems thinking, } \\
\text { including the life cycle } \\
\text { of materials and } \\
\text { products } \\
\text { To better appreciate the } \\
\text { value of diverse human } \\
\text { and natural systems } \\
\text { To introduce basic } \\
\text { ecological concepts } \\
\text { related to the } \\
\text { sustainable food } \\
\text { system, including } \\
\text { energy consumption, } \\
\text { organic cultivation, } \\
\text { farmland conservation, } \\
\text { and food security } \\
\text { To appreciate the role of } \\
\text { design in critical and } \\
\text { strategic thinking } \\
\text { To develop an ability to } \\
\text { translate quantitative } \\
\text { information into } \\
\text { visually and verbally } \\
\text { coherent presentations } \\
\text { and to make an } \\
\text { argument visually and } \\
\text { in written form } \\
\text { To provide a clear } \\
\text { understanding of } \\
\text { the skills to work } \\
\text { collaboratively, } \\
\text { mapping, including the } \\
\text { development of } \\
\text { of tasks according to } \\
\text { skill level, interests, and } \\
\text { leadership capabilities } \\
\text { problem, identify } \\
\text { alternative solutions, } \\
\text { and develop a } \\
\text { prototype or visual } \\
\text { campaign to advance a } \\
\text { isolate, visualize, and } \\
\text { represent in various } \\
\text { formats ecological } \\
\text { phenomena at an urban } \\
\text { scale } \\
\text { To help students } \\
\text { develop skills to explore } \\
\text { the dimensions of a } \\
\text { and }\end{array}$ & $\begin{array}{c}\text { Presentations } \\
\text { Design thinking } \\
\text { project }\end{array}$ \\
\hline
\end{tabular}


TABle 3: Continued.

\begin{tabular}{|c|c|c|c|c|c|}
\hline $\begin{array}{l}\text { First author } \\
\text { (year) }\end{array}$ & Country and institution & Discipline & Students & $\begin{array}{c}\text { Course learning } \\
\text { objectives }\end{array}$ & Course assessments \\
\hline $\begin{array}{l}\text { Dean (2017) } \\
{[31]}\end{array}$ & $\begin{array}{l}\text { AUS, University of } \\
\text { Technology Sydney }\end{array}$ & $\begin{array}{l}\text { Architecture, } \\
\text { Landscape, and } \\
\text { Nursing }\end{array}$ & $\begin{array}{l}\text { Undergraduate } \\
\text { third-year and } \\
\text { postgraduate } \\
\text { students }\end{array}$ & $\begin{array}{l}\text { To develop researched } \\
\text { landscape-focused } \\
\text { architectural solutions } \\
\text { for refuge spaces } \\
\text { To explore the } \\
\text { relationship between } \\
\text { the built and natural } \\
\text { spaces }\end{array}$ & $\begin{array}{l}\text { Design thinking } \\
\text { project } \\
\text { Poster presentation }\end{array}$ \\
\hline $\begin{array}{l}\text { Flammia } \\
(2011) \text { [32] }\end{array}$ & $\begin{array}{l}\text { USA, University of } \\
\text { Central Florida }\end{array}$ & $\begin{array}{l}\text { Biology, Digital Media, } \\
\text { Economics, English, } \\
\text { History, Information } \\
\text { Technology, Nursing, } \\
\text { Politics, Science, Social } \\
\text { Science, and Technical } \\
\text { Communication }\end{array}$ & $\begin{array}{l}\text { Undergraduate } \\
\text { students }\end{array}$ & $\begin{array}{l}\text { To gain a fuller } \\
\text { understanding on a } \\
\text { particular grand } \\
\text { challenge topic and } \\
\text { develop a small local } \\
\text { project to address one } \\
\text { aspect of the topic }\end{array}$ & $\begin{array}{l}\text { Design thinking } \\
\text { project }\end{array}$ \\
\hline $\begin{array}{l}\text { Fomich } \\
\text { (2018) [33] }\end{array}$ & $\begin{array}{c}\text { USA, The Ohio State } \\
\text { University }\end{array}$ & Engineering & $\begin{array}{l}\text { Undergraduate } \\
\text { students }\end{array}$ & $\begin{array}{l}\text { To apply knowledge of } \\
\text { mathematics, science, } \\
\text { and engineering } \\
\text { To design a system, } \\
\text { component, or process } \\
\text { to meet desired needs } \\
\text { To function on } \\
\text { multidisciplinary teams } \\
\text { To identify, formulate, } \\
\text { and solve engineering } \\
\text { problems and use } \\
\text { techniques, skills, and } \\
\text { modern engineering } \\
\text { tools necessary for } \\
\text { engineering practice } \\
\text { To develop an } \\
\text { understanding of } \\
\text { professional and ethical } \\
\text { responsibility } \\
\text { To communicate } \\
\text { effectively } \\
\text { To understand the } \\
\text { impact of engineering } \\
\text { solutions in a global } \\
\text { and societal context } \\
\text { To recognize the need } \\
\text { for, and an ability to } \\
\text { engage in lifelong } \\
\text { learning and develop } \\
\text { knowledge of } \\
\text { contemporary issues }\end{array}$ & $\begin{array}{l}\text { Design thinking } \\
\text { project } \\
\text { Executive summary } \\
\text { report }\end{array}$ \\
\hline
\end{tabular}


TABle 3: Continued.

\begin{tabular}{|c|c|c|c|c|c|}
\hline $\begin{array}{l}\text { First author } \\
\text { (year) }\end{array}$ & Country and institution & Discipline & Students & $\begin{array}{c}\text { Course learning } \\
\text { objectives }\end{array}$ & Course assessments \\
\hline $\begin{array}{l}\text { Forbes } \\
(2018)[34]\end{array}$ & $\begin{array}{l}\text { USA, University of } \\
\text { Nebraska-Lincoln }\end{array}$ & $\begin{array}{c}\text { Agribusiness, } \\
\text { Economics, } \\
\text { Engineering, Fisheries, } \\
\text { History, Hydrology, } \\
\text { Journalism, Math, } \\
\text { Prehealth, Science, } \\
\text { Technology, and } \\
\text { Wildlife Biology }\end{array}$ & $\begin{array}{l}\text { Second-year } \\
\text { undergraduate } \\
\text { students }\end{array}$ & $\begin{array}{l}\text { To explain fundamental } \\
\text { hydrologic concepts } \\
\text { and use this knowledge } \\
\text { to engage in scientific } \\
\text { practices including } \\
\text { posing and answering } \\
\text { scientific questions } \\
\text { To explore hydrologic } \\
\text { phenomena, analyzing } \\
\text { and making inferences } \\
\text { from data, and } \\
\text { determining validity of } \\
\text { conclusions } \\
\text { To engage effectively in } \\
\text { principled analysis of } \\
\text { and reasoning about } \\
\text { sociohydrologic } \\
\text { systems, including their } \\
\text { scientific, ethical, social, } \\
\text { economic, cultural, and } \\
\text { civic dimensions, to } \\
\text { make informed } \\
\text { decisions about water } \\
\text { resource use }\end{array}$ & $\begin{array}{l}\text { Student discussions } \\
\text { Presentation of } \\
\text { infographics to } \\
\text { scientists, } \\
\text { policymakers, and } \\
\text { educators at a global } \\
\text { conference }\end{array}$ \\
\hline $\begin{array}{l}\text { Fortner } \\
(2016)[20]\end{array}$ & $\begin{array}{c}\text { USA, Wittenberg } \\
\text { University, Virginia } \\
\text { Tech, Santa Rosa Junior } \\
\text { College }\end{array}$ & $\begin{array}{c}\text { Agriculture, Ecological } \\
\text { Sciences, } \\
\text { Environmental } \\
\text { Sciences, Geology, and } \\
\text { some Non-Science } \\
\text { majors }\end{array}$ & $\begin{array}{l}\text { Undergraduate } \\
\text { students }\end{array}$ & $\begin{array}{c}\text { To develop a plan for } \\
\text { sustainable soil } \\
\text { management in one or } \\
\text { more agricultural } \\
\text { settings using geologic } \\
\text { data } \\
\text { To predict agricultural } \\
\text { challenges that might } \\
\text { result from climate } \\
\text { change }\end{array}$ & $\begin{array}{l}\text { Creation of a fact } \\
\text { sheet }\end{array}$ \\
\hline $\begin{array}{l}\text { Fortuin } \\
\text { (2013) [35] }\end{array}$ & $\begin{array}{l}\text { NLD, Wageningen } \\
\text { University }\end{array}$ & $\begin{array}{c}\text { Economics, } \\
\text { Humanities, Natural } \\
\text { Sciences, Social } \\
\text { Sciences, and } \\
\text { Technology }\end{array}$ & $\begin{array}{c}\text { BSc and MSc } \\
\text { environmental } \\
\text { science students }\end{array}$ & $\begin{array}{l}\text { To holistically develop } \\
\text { an understanding of the } \\
\text { environmental issues } \\
\text { To identify, understand, } \\
\text { appraise, and connect } \\
\text { disciplinary knowledge } \\
\text { To reflect on the role of } \\
\text { science in solving } \\
\text { environmental } \\
\text { problems }\end{array}$ & $\begin{array}{c}\text { Scientific report } \\
\text { Design thinking } \\
\text { project } \\
\text { Reflection papers }\end{array}$ \\
\hline $\begin{array}{l}\text { Gama (2018) } \\
{[36]}\end{array}$ & $\begin{array}{l}\text { BRA, Federal University } \\
\text { of Pernambuco } \\
\text { CAN, McGill University }\end{array}$ & $\begin{array}{l}\text { Computer Science and } \\
\text { Information Systems }\end{array}$ & $\begin{array}{l}\text { Undergraduate } \\
\text { students }\end{array}$ & $\begin{array}{l}\text { To find ways to grow } \\
\text { quality vegetables in a } \\
\text { domestic environment } \\
\text { To predict and identify } \\
\text { possible sources of fire } \\
\text { in private rural estates }\end{array}$ & $\begin{array}{l}\text { Design thinking } \\
\text { project }\end{array}$ \\
\hline
\end{tabular}


TABle 3: Continued.

\begin{tabular}{|c|c|c|c|c|c|}
\hline $\begin{array}{l}\text { First author } \\
\text { (year) }\end{array}$ & Country and institution & Discipline & Students & $\begin{array}{c}\text { Course learning } \\
\text { objectives }\end{array}$ & Course assessments \\
\hline $\begin{array}{l}\text { Gardner } \\
(2010)[37]\end{array}$ & $\begin{array}{c}\text { USA, New York } \\
\text { University }\end{array}$ & Social Work & Masters students & $\begin{array}{c}\text { To assess the } \\
\text { community well-being } \\
\text { of low-income urban } \\
\text { residents } \\
\text { To develop, analyze, } \\
\text { and propose policies, } \\
\text { programs, and services } \\
\text { that support the needs } \\
\text { of vulnerable } \\
\text { community members } \\
\text { To promote a broader, } \\
\text { more critical } \\
\text { understanding of the } \\
\text { multiple and } \\
\text { interacting factors that } \\
\text { negatively affect poor } \\
\text { individuals and families } \\
\text { in urban communities }\end{array}$ & $\begin{array}{c}\text { Essays } \\
\text { Poster presentation }\end{array}$ \\
\hline $\begin{array}{l}\text { Gillet (2019) } \\
\text { [38] }\end{array}$ & $\begin{array}{l}\text { USA, University of } \\
\text { Michigan }\end{array}$ & $\begin{array}{l}\text { Management and } \\
\text { Education } \\
\text { (multidisciplinary) }\end{array}$ & $\begin{array}{l}\text { Undergraduate } \\
\text { students }\end{array}$ & $\begin{array}{l}\text { To build global } \\
\text { competence and career } \\
\text { readiness skills for } \\
\text { young people in the } \\
\text { United States and } \\
\text { across the Middle East } \\
\text { and North Africa (the } \\
\text { MENA region) }\end{array}$ & $\begin{array}{l}\text { Design thinking } \\
\text { project } \\
\text { Video presentation } \\
\text { of the suggested } \\
\text { entrepreneurial } \\
\text { solutions }\end{array}$ \\
\hline
\end{tabular}

To explain water projects to nontechnical people and assess implications of technical and nontechnical water project solutions and decisions in a societal context

To develop effective communication with others to develop,
USA, University of Nebraska-Lincoln, The

Gosselin

Chester University, (2016) [39] niversity of Utah, West Engineering, Math, and Metropolitan State University disciplines (interdisciplinary)

\section{Technology,}

Undergraduate judge, and recommend multiobjective solutions to water resource challenges

To think critically and analytically across

disciplinary boundaries about connections between natural, social, and economic systems To make informed decisions and ethical choices by actualizing sustainability as a system dependent on both fact and value

To design a solution to a political or social problem
Upper-level undergraduate students
Papers and Essays Design thinking project

\section{Griffin}

(2011) [40]
USA, University of Nebraska-Lincoln
Political Science
Design thinking project

Presentations

Essays 
TABle 3: Continued.

\begin{tabular}{|c|c|c|c|c|c|}
\hline $\begin{array}{l}\text { First author } \\
\text { (year) }\end{array}$ & Country and institution & Discipline & Students & $\begin{array}{c}\text { Course learning } \\
\text { objectives }\end{array}$ & Course assessments \\
\hline $\begin{array}{l}\text { Grose (2014) } \\
{[21]}\end{array}$ & $\begin{array}{c}\text { USA, Arizona State } \\
\text { University, Bucknell } \\
\text { University, Rose- } \\
\text { Hulman Institute of } \\
\text { Technology, Bucknell } \\
\text { University, Duke } \\
\text { University }\end{array}$ & Engineering & $\begin{array}{l}\text { Undergraduate } \\
\text { students }\end{array}$ & $\begin{array}{l}\text { To design, build, and } \\
\text { test materials that can } \\
\text { help the developing } \\
\text { world }\end{array}$ & $\begin{array}{c}\text { Design thinking } \\
\text { project } \\
\text { Essays } \\
\text { Presentations } \\
\text { Reflections }\end{array}$ \\
\hline $\begin{array}{l}\text { Hogfeldt } \\
(2019)[41]\end{array}$ & $\begin{array}{c}\text { SWE, KTH Royal } \\
\text { Institute of Technology } \\
\text { TZA, University of Dar } \\
\text { es Salaam }\end{array}$ & Engineering & $\begin{array}{l}\text { Undergraduate and } \\
\text { graduate students }\end{array}$ & $\begin{array}{c}\text { To apply design } \\
\text { thinking methodology } \\
\text { to address water and } \\
\text { sanitation issues }\end{array}$ & $\begin{array}{c}\text { Design thinking } \\
\text { project } \\
\text { Presentations }\end{array}$ \\
\hline $\begin{array}{l}\text { Hasan (2017) } \\
{[42]}\end{array}$ & $\begin{array}{l}\text { AUS, University of } \\
\text { Wollongong }\end{array}$ & $\begin{array}{l}\text { Computer Science, } \\
\text { Green Information } \\
\text { Systems, and } \\
\text { Information } \\
\text { Communication } \\
\text { Technology }\end{array}$ & $\begin{array}{c}\text { Professors, } \\
\text { undergraduate. } \\
\text { postgraduate } \\
\text { students, and } \\
\text { representatives from } \\
\text { local businesses }\end{array}$ & $\begin{array}{l}\text { To identify a problem, } \\
\text { define the obstacles in } \\
\text { reaching a solution, } \\
\text { design, develop, and } \\
\text { demonstrate a solution, } \\
\text { and communicate } \\
\text { findings }\end{array}$ & $\begin{array}{l}\text { Design thinking } \\
\text { project }\end{array}$ \\
\hline $\begin{array}{l}\text { Hecht (2014) } \\
{[23]}\end{array}$ & $\begin{array}{c}\text { USA, Massachusetts } \\
\text { Institute of Technology } \\
\text { Media Lab } \\
\text { iNDOVATION and } \\
\text { Engineering colleges, } \\
\text { India }\end{array}$ & Engineering & $\begin{array}{l}\text { Undergraduate and } \\
\text { graduate students, } \\
\text { high school students, } \\
\text { technology } \\
\text { professors, } \\
\text { entrepreneurs }\end{array}$ & $\begin{array}{c}\text { To build and test } \\
\text { prototypes of hardware, } \\
\text { sensors, and mobile } \\
\text { apps for surge } \\
\text { population attendance } \\
\text { in advance of Kumbh } \\
\text { Mela Festival }\end{array}$ & $\begin{array}{l}\text { Design thinking } \\
\text { project }\end{array}$ \\
\hline $\begin{array}{l}\text { Heinricher } \\
(2008)[22]\end{array}$ & $\begin{array}{c}\text { USA, Worcester } \\
\text { Polytechnic Institute }\end{array}$ & $\begin{array}{c}\text { Aerospace Engineering, } \\
\text { Biology, Biomedical } \\
\text { Engineering, Chemical } \\
\text { Engineering, } \\
\text { Chemistry, Civil } \\
\text { Engineering, Computer } \\
\text { Engineering, Electrical } \\
\text { Engineering, and } \\
\text { Mechanical } \\
\text { Engineering }\end{array}$ & $\begin{array}{l}\text { First-year } \\
\text { undergraduate } \\
\text { students }\end{array}$ & $\begin{array}{c}\text { To engage with current } \\
\text { events, societal } \\
\text { problems, and human } \\
\text { needs } \\
\text { To engage in critical } \\
\text { thinking, information } \\
\text { literacy, and evidence- } \\
\text { based writing } \\
\text { To develop effective } \\
\text { teamwork, time } \\
\text { management, } \\
\text { organization, and } \\
\text { personal responsibility } \\
\text { skills }\end{array}$ & $\begin{array}{l}\text { Report writing } \\
\text { Presentations } \\
\text { Group discussions } \\
\text { Miniprojects } \\
\text { “Adventure } \\
\text { assignments" }\end{array}$ \\
\hline $\begin{array}{l}\text { Holzer } \\
(2016)[43]\end{array}$ & $\begin{array}{c}\text { CHE, Ecole } \\
\text { Polytechnique Fédérale } \\
\text { de Lausanne, Université } \\
\text { de Lausanne, } \\
\text { ITA, University of } \\
\text { Ferrara }\end{array}$ & $\begin{array}{l}\text { Engineering, Science, } \\
\text { and Social Science }\end{array}$ & $\begin{array}{l}\text { First-year } \\
\text { undergraduate } \\
\text { students }\end{array}$ & $\begin{array}{c}\text { To show the links } \\
\text { between technological } \\
\text { solutions and societal } \\
\text { issues } \\
\text { To guide future } \\
\text { scientists and engineers } \\
\text { to become responsible } \\
\text { citizens, and develop } \\
\text { critical thinking around } \\
\text { global issues }\end{array}$ & $\begin{array}{l}\text { Design thinking } \\
\text { project } \\
\text { Presentation } \\
\text { Self-reflection } \\
\text { Posters }\end{array}$ \\
\hline $\begin{array}{l}\text { Jahan (2019) } \\
{[44]}\end{array}$ & USA, Rowan University & $\begin{array}{l}\text { Engineering (integrates } \\
\text { engineering and } \\
\text { humanities/social } \\
\text { sciences content) }\end{array}$ & $\begin{array}{l}69 \text { first-year } \\
\text { undergraduate } \\
\text { students }\end{array}$ & $\begin{array}{l}\text { To engage in project- } \\
\text { based learning using a } \\
\text { living organism } \\
\text { To learn about } \\
\text { engineering } \\
\text { fundamentals and core } \\
\text { concepts from } \\
\text { humanities }\end{array}$ & $\begin{array}{l}\text { Design thinking } \\
\text { project } \\
\text { Presentations } \\
\text { Classroom-based } \\
\text { discussions }\end{array}$ \\
\hline
\end{tabular}


TABle 3: Continued.

\begin{tabular}{|c|c|c|c|c|c|}
\hline $\begin{array}{l}\text { First author } \\
\text { (year) }\end{array}$ & Country and institution & Discipline & Students & $\begin{array}{c}\text { Course learning } \\
\text { objectives }\end{array}$ & Course assessments \\
\hline $\begin{array}{l}\text { Johannes } \\
\text { (1996) [45] }\end{array}$ & $\begin{array}{c}\text { NLD, University of } \\
\text { Technology Eindhoven }\end{array}$ & Engineering & & $\begin{array}{c}\text { To emphasize } \\
\text { interdisciplinary work } \\
\text { and promote } \\
\text { cooperation within a } \\
\text { group } \\
\text { To acquire and apply a } \\
\text { systematic approach to } \\
\text { problem-solving }\end{array}$ & $\begin{array}{l}\text { Design thinking } \\
\text { project }\end{array}$ \\
\hline $\begin{array}{l}\text { Jonker } \\
\text { (2019) [46] }\end{array}$ & $\begin{array}{l}\text { NLD, Institute for } \\
\text { Management Research, } \\
\text { Nijmegen School of } \\
\text { Management, Radboud } \\
\text { University Nijmegen }\end{array}$ & Business & $\begin{array}{l}\text { Graduate students } \\
\text { and third-year } \\
\text { undergraduate } \\
\text { students }\end{array}$ & $\begin{array}{c}\text { To learn about } \\
\text { sustainability concepts } \\
\text { from a management } \\
\text { and business } \\
\text { perspective }\end{array}$ & $\begin{array}{c}\text { Design thinking } \\
\text { project } \\
\text { Learning portfolios }\end{array}$ \\
\hline $\begin{array}{l}\text { Judge (2020) } \\
\text { [47] }\end{array}$ & $\begin{array}{c}\text { USA, Roger Williams } \\
\text { University, University of } \\
\text { Rhode Island, } \\
\text { Northeastern University, } \\
\text { GNCB Consulting } \\
\text { Engineers, United States } \\
\text { Naval Academy, } \\
\text { University of } \\
\text { Massachusetts }\end{array}$ & $\begin{array}{l}\text { Architecture, Ecology. } \\
\text { Landscape, } \\
\text { Engineering, Physical } \\
\text { Sciences, and Social } \\
\text { Sciences }\end{array}$ & Graduate students & $\begin{array}{l}\text { To bridge the gap } \\
\text { between research and } \\
\text { practice regarding the } \\
\text { design of resilient } \\
\text { infrastructure for } \\
\text { coastal adaptation } \\
\text { To develop a resilience- } \\
\text { improving hybrid } \\
\text { structural/social/ } \\
\text { ecological } \\
\text { infrastructure design } \\
\text { for a particular site }\end{array}$ & $\begin{array}{c}\text { Design thinking } \\
\text { project } \\
\text { Presentation }\end{array}$ \\
\hline $\begin{array}{l}\text { Kienzler } \\
(2017) \text { [24] }\end{array}$ & $\begin{array}{l}\text { GRB, King's College, } \\
\text { London } \\
\text { USA, George } \\
\text { Washington University }\end{array}$ & Social Sciences & $\begin{array}{l}\text { Undergraduate } \\
\text { students }\end{array}$ & $\begin{array}{l}\text { To gain and create } \\
\text { knowledge about } \\
\text { specific global health- } \\
\text { related challenges } \\
\text { To acquire tangible and } \\
\text { transferable skills being } \\
\text { a part of the course } \\
\text { To define global health } \\
\text { and how it might be } \\
\text { secured } \\
\text { To understand the } \\
\text { knowledge-to-action } \\
\text { gap in different fields of } \\
\text { global health and the } \\
\text { strategies that aim to } \\
\text { close it } \\
\text { To develop skills } \\
\text { needed to critically } \\
\text { evaluate initiatives and } \\
\text { identify the role of key } \\
\text { stakeholders in shaping } \\
\text { them } \\
\text { To demonstrate the } \\
\text { value of } \\
\text { interdisciplinary } \\
\text { approaches to global } \\
\text { health } \\
\text { To use methodological } \\
\text { and epistemological } \\
\text { tools in the production } \\
\text { of global health } \\
\text { research }\end{array}$ & $\begin{array}{c}\text { Essay } \\
\text { Infographic Poster } \\
\text { Public presentation }\end{array}$ \\
\hline
\end{tabular}


TABle 3: Continued.

\begin{tabular}{|c|c|c|c|c|c|}
\hline $\begin{array}{l}\text { First author } \\
\text { (year) }\end{array}$ & Country and institution & Discipline & Students & $\begin{array}{c}\text { Course learning } \\
\text { objectives }\end{array}$ & Course assessments \\
\hline $\begin{array}{l}\text { Kim }(2018) \\
{[48]}\end{array}$ & $\begin{array}{l}\text { USA, Purdue University, } \\
\text { John Hopkins University }\end{array}$ & Engineering & $\begin{array}{l}\text { Undergraduate } \\
\text { students }\end{array}$ & $\begin{array}{l}\text { To develop a problem } \\
\text { statement by } \\
\text { identifying explicit and } \\
\text { implicit goals, } \\
\text { determining the } \\
\text { constraints involved in } \\
\text { a given problem, and } \\
\text { considering multiple } \\
\text { perspectives regarding } \\
\text { the design scenario to } \\
\text { help eliminate any } \\
\text { perceived assumptions } \\
\text { that unnecessarily limit } \\
\text { the problem-solving } \\
\text { process } \\
\text { To plan and manage a } \\
\text { design project by } \\
\text { applying a variety of } \\
\text { project management } \\
\text { strategies }\end{array}$ & $\begin{array}{c}\text { Design thinking } \\
\text { project } \\
\text { Concept map } \\
\text { Presentations }\end{array}$ \\
\hline
\end{tabular}

\begin{tabular}{|c|c|c|c|c|c|}
\hline $\begin{array}{l}\text { Knudson } \\
\text { (2011) [49] }\end{array}$ & $\begin{array}{l}\text { USA, University of } \\
\text { California }\end{array}$ & $\begin{array}{c}\text { Anthropology, } \\
\text { Chemistry, Community } \\
\text { Development, Design, } \\
\text { Ecology, Education, } \\
\text { Engineering, } \\
\text { Environmental } \\
\text { Resources, Geography, } \\
\text { Physics and Soil Science }\end{array}$ & Graduate students & $\begin{array}{c}\text { To develop } \\
\text { environmental leaders } \\
\text { through a professional } \\
\text { development } \\
\text { mentoring program }\end{array}$ & $\begin{array}{c}\text { Design thinking } \\
\text { project } \\
\text { Presentations }\end{array}$ \\
\hline $\begin{array}{l}\text { Leon }(2015) \\
{[50]}\end{array}$ & USA, Emory University & Global Health & $\begin{array}{c}\text { First-year students of } \\
\text { Master of Public } \\
\text { Health }\end{array}$ & $\begin{array}{l}\text { To integrate core public } \\
\text { health disciplines into } \\
\text { team-based problem- } \\
\text { solving around } \\
\text { authentic global health } \\
\text { challenges }\end{array}$ & $\begin{array}{l}\text { Written reports } \\
\text { Class discussions } \\
\text { Presentations }\end{array}$ \\
\hline $\begin{array}{l}\operatorname{Lim}(2016) \\
{[51]}\end{array}$ & $\begin{array}{c}\text { AUS, Griffith University } \\
\text { GRB, University of } \\
\text { Dundee }\end{array}$ & $\begin{array}{l}\text { Law, Natural Sciences, } \\
\text { and Social Sciences }\end{array}$ & Graduate students & $\begin{array}{l}\text { To bring together } \\
\text { expertise from the } \\
\text { natural and social } \\
\text { sciences } \\
\text { To link priorities and } \\
\text { preferences expressed } \\
\text { by decision-makers } \\
\text { with regard to issues } \\
\text { concerning the } \\
\text { environment, land and } \\
\text { natural resource use, } \\
\text { and livelihood }\end{array}$ & $\begin{array}{l}\text { Design thinking } \\
\text { project } \\
\text { Class presentations }\end{array}$ \\
\hline $\begin{array}{l}\text { Nagarajan } \\
(2019)[52]\end{array}$ & $\begin{array}{c}\text { USA, Bowling Green } \\
\text { State University } \\
\text { AUS, Monash University }\end{array}$ & Chemistry & $\begin{array}{l}\text { Undergraduate } \\
\text { students }\end{array}$ & $\begin{array}{l}\text { To educate students on } \\
\text { the principles and } \\
\text { importance of green } \\
\text { chemistry, circular } \\
\text { economy, recycling, } \\
\text { and life cycle analysis }\end{array}$ & $\begin{array}{l}\text { Design thinking } \\
\text { project }\end{array}$ \\
\hline $\begin{array}{l}\text { Nichols } \\
\text { (2019) [53] }\end{array}$ & $\begin{array}{c}\text { USA, South Dakota State } \\
\text { University }\end{array}$ & $\begin{array}{l}\text { Agriculture, Arts, } \\
\text { Sciences, Biological } \\
\text { Sciences, Education, } \\
\text { Engineering, and } \\
\text { Human Sciences }\end{array}$ & $\begin{array}{l}\text { Undergraduate } \\
\text { students }\end{array}$ & $\begin{array}{c}\text { To support } \\
\text { interdisciplinary } \\
\text { undergraduate research } \\
\text { experiences }\end{array}$ & $\begin{array}{c}\text { Design thinking } \\
\text { project } \\
\text { Presentations }\end{array}$ \\
\hline
\end{tabular}


TABle 3: Continued.

\begin{tabular}{|c|c|c|c|c|c|}
\hline $\begin{array}{l}\text { First author } \\
\text { (year) }\end{array}$ & Country and institution & Discipline & Students & $\begin{array}{c}\text { Course learning } \\
\text { objectives }\end{array}$ & Course assessments \\
\hline $\begin{array}{l}\text { Nitkin } \\
(2016)[54]\end{array}$ & $\begin{array}{c}\text { USA, Simmons College, } \\
\text { Worcester State } \\
\text { University }\end{array}$ & & Sophomore level & $\begin{array}{l}\text { To understand the local } \\
\text { and global social, } \\
\text { economic, political, and } \\
\text { cultural dynamics } \\
\text { related to a societal } \\
\text { challenge, as well as the } \\
\text { strengths and } \\
\text { weaknesses of existing } \\
\text { responses to the } \\
\text { problem } \\
\text { To develop } \\
\text { organizational and } \\
\text { communication skills } \\
\text { needed to work } \\
\text { effectively in teams } \\
\text { To formulate creative } \\
\text { and actionable } \\
\text { solutions to the } \\
\text { challenge }\end{array}$ & $\begin{array}{c}\text { Design thinking } \\
\text { project } \\
\text { Presentations }\end{array}$ \\
\hline $\begin{array}{l}\text { Nurius } \\
(2017)[55]\end{array}$ & $\begin{array}{l}\text { USA, University of } \\
\text { Washington, University } \\
\text { of Texas, University of } \\
\text { Illinois, Boston College }\end{array}$ & Social Work & $\begin{array}{l}\text { Undergraduate and } \\
\text { graduate students }\end{array}$ & $\begin{array}{c}\text { To develop } \\
\text { entrepreneurial } \\
\text { thinking and leadership } \\
\text { skills and practice these } \\
\text { skills inside and outside } \\
\text { of the classroom with } \\
\text { diverse, } \\
\text { interdisciplinary teams }\end{array}$ & $\begin{array}{l}\text { Design thinking } \\
\text { proposal }\end{array}$ \\
\hline $\begin{array}{l}\text { Piens (2015) } \\
{[56]}\end{array}$ & $\begin{array}{l}\text { USA, Rose-Hulman } \\
\text { Institute of Technology }\end{array}$ & $\begin{array}{c}\text { Engineering, } \\
\text { Humanities, and Social } \\
\text { Sciences }\end{array}$ & $\begin{array}{l}\text { Undergraduate } \\
\text { students }\end{array}$ & $\begin{array}{l}\text { To develop and design a } \\
\text { project for Haiti } \\
\text { disaster relief } \\
\text { addressing the housing } \\
\text { crisis }\end{array}$ & $\begin{array}{l}\text { Design thinking } \\
\text { project }\end{array}$ \\
\hline $\begin{array}{l}\text { Radberg } \\
(2018) \text { [57] }\end{array}$ & $\begin{array}{c}\text { SWE, Chalmers } \\
\text { University of Technology }\end{array}$ & $\begin{array}{l}\text { Civil Engineering, } \\
\text { Energy, Environmental } \\
\text { Studies, Maritime } \\
\text { Engineering, Physics, } \\
\text { and Technology } \\
\text { Management }\end{array}$ & Masters students & $\begin{array}{l}\text { To describe critical } \\
\text { sustainability } \\
\text { challenges, their } \\
\text { connection with, and } \\
\text { effect on industrial and } \\
\text { societal actors } \\
\text { To reflect on the } \\
\text { challenges of policy } \\
\text { implementation for } \\
\text { sustainable } \\
\text { development } \\
\text { To apply a systems } \\
\text { perspective to meet } \\
\text { sustainability } \\
\text { challenges and apply } \\
\text { practical methods and } \\
\text { tools for sustainable } \\
\text { product development } \\
\text { and design }\end{array}$ & $\begin{array}{l}\text { Design thinking } \\
\text { project }\end{array}$ \\
\hline
\end{tabular}


TABle 3: Continued.

\begin{tabular}{|c|c|c|c|c|c|}
\hline $\begin{array}{l}\text { First author } \\
\text { (year) }\end{array}$ & Country and institution & Discipline & Students & $\begin{array}{c}\text { Course learning } \\
\text { objectives }\end{array}$ & Course assessments \\
\hline $\begin{array}{l}\text { Reichmanis } \\
(2017)[58]\end{array}$ & $\begin{array}{c}\text { USA, Georgia Institute of } \\
\text { Technology }\end{array}$ & $\begin{array}{l}\text { Biochemistry, } \\
\text { Chemistry, } \\
\text { Engineering, and } \\
\text { Material Science }\end{array}$ & & $\begin{array}{l}\text { To understand how } \\
\text { chemicals can be used/ } \\
\text { integrated into } \\
\text { products to achieve the } \\
\text { best benefit to } \\
\text { customers while } \\
\text { minimizing life cycle } \\
\text { sustainability impacts } \\
\text { To make decisions } \\
\text { taking into account life } \\
\text { cycle thinking and } \\
\text { systems analysis }\end{array}$ & $\begin{array}{l}\text { Design thinking } \\
\text { project }\end{array}$ \\
\hline $\begin{array}{l}\text { Richards- } \\
\text { Kortum } \\
\text { (2012) [59] }\end{array}$ & USA, Rice University & Engineering & $\begin{array}{l}\text { Undergraduate } \\
\text { students }\end{array}$ & $\begin{array}{l}\text { To use the engineering } \\
\text { design process to } \\
\text { develop innovative } \\
\text { technologies addressing } \\
\text { global health challenges }\end{array}$ & $\begin{array}{l}\text { Design thinking } \\
\text { project } \\
\text { Presentations }\end{array}$ \\
\hline $\begin{array}{l}\text { Rodríguez } \\
(2019)[60]\end{array}$ & $\begin{array}{c}\text { USA, University of } \\
\text { Illinois, University of } \\
\text { Nebraska-Lincoln, Iowa } \\
\text { State University, } \\
\text { University of California, } \\
\text { North Carolina State } \\
\text { University, University of } \\
\text { Minnesota, Northern } \\
\text { Arizona University, } \\
\text { University of Louisiana, } \\
\text { Johns Hopkins } \\
\text { University }\end{array}$ & $\begin{array}{c}\text { Biological Sciences, } \\
\text { Engineering, Physical } \\
\text { Sciences, and Social } \\
\text { Sciences }\end{array}$ & Graduate students & $\begin{array}{c}\text { To ask transdisciplinary } \\
\text { questions across } \\
\text { disciplinary boundaries } \\
\text { to build on existing } \\
\text { sources of knowledge } \\
\text { and to understand and } \\
\text { design innovative } \\
\text { solutions }\end{array}$ & $\begin{array}{l}\text { Design thinking } \\
\text { project }\end{array}$ \\
\hline $\begin{array}{l}\text { Sienko } \\
(2013)[61]\end{array}$ & $\begin{array}{l}\text { USA, University of } \\
\text { Michigan, Humboldt } \\
\text { State University }\end{array}$ & Engineering & $\begin{array}{l}\text { Fifteen students } \\
\text { from Mechanical } \\
\text { Engineering, } \\
\text { Biomedical } \\
\text { Engineering, and the } \\
\text { School of } \\
\text { Information }\end{array}$ & $\begin{array}{c}\text { To focus on } \\
\text { technologies that are } \\
\text { designed to prevent, } \\
\text { diagnose, or treat the } \\
\text { top ten leading causes } \\
\text { of death in low-income } \\
\text { and middle-income } \\
\text { countries, as well as } \\
\text { maternal and infant } \\
\text { health }\end{array}$ & $\begin{array}{l}\text { Group report } \\
\text { Class discussions }\end{array}$ \\
\hline $\begin{array}{l}\text { Tandon } \\
(2017)[25]\end{array}$ & $\begin{array}{c}\text { USA, California State } \\
\text { University }\end{array}$ & $\begin{array}{l}\text { Engineering and } \\
\text { Science }\end{array}$ & $\begin{array}{l}\text { Undergraduate and } \\
\text { graduate students }\end{array}$ & $\begin{array}{l}\text { To promote } \\
\text { engineering education } \\
\text { in the context of } \\
\text { mosquito-borne } \\
\text { illnesses, a relevant } \\
\text { real-world problems }\end{array}$ & $\begin{array}{l}\text { Design thinking } \\
\text { project } \\
\text { Presentations }\end{array}$ \\
\hline
\end{tabular}


TABle 3: Continued.

\begin{tabular}{|c|c|c|c|c|c|}
\hline $\begin{array}{l}\text { First author } \\
\text { (year) }\end{array}$ & Country and institution & Discipline & Students & $\begin{array}{c}\text { Course learning } \\
\text { objectives }\end{array}$ & Course assessments \\
\hline $\begin{array}{l}\text { Telenko } \\
\text { (2016) [62] }\end{array}$ & $\begin{array}{c}\text { USA, Georgia Institute of } \\
\text { Technology } \\
\text { SGP, Singapore } \\
\text { University of Technology } \\
\text { and Design } \\
\text { LUX, Université du } \\
\text { Luxembourg } \\
\text { USA, Massachusetts } \\
\text { Institute of Technology }\end{array}$ & Engineering & & $\begin{array}{c}\text { To understand the } \\
\text { engineering subject } \\
\text { fundamentals } \\
\text { To reflect, observe and } \\
\text { hypothesize, and assess } \\
\text { contexts, opportunities, } \\
\text { and needs } \\
\text { To ideate and abstract } \\
\text { using multiple } \\
\text { representations } \\
\text { To make decisions for } \\
\text { open-ended, design } \\
\text { problems and creatively } \\
\text { utilise resources within } \\
\text { a complex system }\end{array}$ & $\begin{array}{l}\text { Design thinking } \\
\text { project }\end{array}$ \\
\hline $\begin{array}{l}\text { Trowbridge } \\
\text { (2018) [63] }\end{array}$ & $\begin{array}{l}\text { USA, Arizona State } \\
\text { University }\end{array}$ & Engineering & $\begin{array}{c}\text { First-year } \\
\text { engineering students }\end{array}$ & $\begin{array}{l}\text { To develop talent, } \\
\text { multidisciplinary, } \\
\text { viable business/ } \\
\text { entrepreneurship, } \\
\text { multicultural, and } \\
\text { social consciousness } \\
\text { competencies needed to } \\
\text { solve global challenges }\end{array}$ & $\begin{array}{l}\text { Design thinking } \\
\text { project } \\
\text { Digital portfolios } \\
\text { Reflection }\end{array}$ \\
\hline $\begin{array}{l}\text { Udugama } \\
\text { (2018) [64] }\end{array}$ & $\begin{array}{l}\text { DNK, Technical } \\
\text { University of Denmark } \\
\text { Universitetsparken, } \\
\text { University of } \\
\text { Copenhagen } \\
\text { GRB, Newcastle } \\
\text { University }\end{array}$ & Biotechnology & $\begin{array}{l}\text { Postgraduate } \\
\text { students }\end{array}$ & $\begin{array}{l}\text { To learn cutting edge, } \\
\text { industrially relevant } \\
\text { knowledge about } \\
\text { industrial scale bio- } \\
\text { based production } \\
\text { processes } \\
\text { To build relevant soft } \\
\text { skills } \\
\text { To facilitate working in } \\
\text { a multicultural and } \\
\text { multidisciplinary group }\end{array}$ & $\begin{array}{l}\text { Design thinking } \\
\text { project }\end{array}$ \\
\hline
\end{tabular}


TABle 3: Continued.

\begin{tabular}{|c|c|c|c|c|c|}
\hline $\begin{array}{l}\text { First author } \\
\text { (year) }\end{array}$ & Country and institution & Discipline & Students & $\begin{array}{c}\text { Course learning } \\
\text { objectives }\end{array}$ & Course assessments \\
\hline $\begin{array}{l}\text { White (2018) } \\
\text { [65] }\end{array}$ & $\begin{array}{l}\text { USA, no specific } \\
\text { institution listed }\end{array}$ & Engineering & $\begin{array}{c}\text { Mechanical } \\
\text { Engineering doctoral } \\
\text { candidate, along with } \\
15 \text { new university } \\
\text { first-year students }\end{array}$ & $\begin{array}{l}\text { To explore how } \\
\text { engineering solutions } \\
\text { can be used to support } \\
\text { the basic human needs } \\
\text { of the world's } \\
\text { population } \\
\text { To understand how } \\
\text { engineering solutions } \\
\text { are impacted by the } \\
\text { surrounding economic, } \\
\text { environmental, and } \\
\text { societal context } \\
\text { To explore how } \\
\text { engineering solutions } \\
\text { may impact global } \\
\text { society and how culture } \\
\text { and political } \\
\text { philosophies impact the } \\
\text { appropriateness and } \\
\text { sustainability of } \\
\text { engineering solutions } \\
\text { To explore the influence } \\
\text { of a given culture on the } \\
\text { engineering solutions } \\
\text { used in that culture } \\
\text { To design and } \\
\text { implement engineering } \\
\text { solutions addressing } \\
\text { the needs, both from a } \\
\text { practical and cultural } \\
\text { perspective, of a range } \\
\text { of communities } \\
\text { including those that are } \\
\text { currently } \\
\text { disadvantaged }\end{array}$ & $\begin{array}{c}\text { Service learning } \\
\text { Reflections } \\
\text { Discussions }\end{array}$ \\
\hline $\begin{array}{l}\text { White (2017) } \\
\text { [66] }\end{array}$ & $\begin{array}{l}\text { USA, University of New } \\
\text { Hampshire, University of } \\
\text { Arizona, University of } \\
\text { Dubuque University of } \\
\text { Nebraska, University of } \\
\text { California }\end{array}$ & Geosciences & $\begin{array}{l}\text { Undergraduate } \\
\text { students }\end{array}$ & $\begin{array}{l}\text { To introduce the } \\
\text { interdisciplinary } \\
\text { science needed to } \\
\text { understand the Critical } \\
\text { Zone (CZ) of earth } \\
\text { To examine } \\
\text { geosciences-related } \\
\text { grand challenges facing } \\
\text { society, especially soil } \\
\text { and ecosystem services } \\
\text { To address } \\
\text { interdisciplinary } \\
\text { problems by using data } \\
\text { visualization and } \\
\text { analysis skills with } \\
\text { authentic data } \\
\text { To incorporate systems } \\
\text { thinking by employing } \\
\text { examples and activities } \\
\text { that demonstrate the } \\
\text { connection between } \\
\text { water, air, soil, and } \\
\text { organisms in } \\
\text { biogeochemical } \\
\text { processes }\end{array}$ & $\begin{array}{l}\text { In-class discussions } \\
\text { Presentations } \\
\text { Essay and report } \\
\text { writing }\end{array}$ \\
\hline
\end{tabular}


TABle 3: Continued.

\begin{tabular}{|c|c|c|c|c|c|}
\hline $\begin{array}{l}\text { First author } \\
\text { (year) }\end{array}$ & Country and institution & Discipline & Students & $\begin{array}{c}\text { Course learning } \\
\text { objectives }\end{array}$ & Course assessments \\
\hline $\begin{array}{l}\text { White (2014) } \\
\text { [67] }\end{array}$ & $\begin{array}{l}\text { USA, Worcester State } \\
\text { University, Simmons } \\
\text { College }\end{array}$ & $\begin{array}{l}\text { Communications, Lab } \\
\text { Science, Liberal Arts, } \\
\text { Library Science, } \\
\text { Mathematics, } \\
\text { Management, Nursing, } \\
\text { Nutrition, Science, } \\
\text { Social Work, and } \\
\text { Sociology }\end{array}$ & $\begin{array}{l}\text { Undergraduate } \\
\text { students }\end{array}$ & $\begin{array}{l}\text { To acquire a working } \\
\text { knowledge of the global } \\
\text { social problem, } \\
\text { including an } \\
\text { understanding of local } \\
\text { and global social, } \\
\text { economic, political, and } \\
\text { cultural dynamics and } \\
\text { existing responses } \\
\text { To develop the practical } \\
\text { organizational, } \\
\text { technical, research, and } \\
\text { communication skills } \\
\text { to work effectively and } \\
\text { efficiently in teams } \\
\text { To formulate creative } \\
\text { and actionable } \\
\text { solutions to address the } \\
\text { global social problem }\end{array}$ & $\begin{array}{l}\text { Design thinking } \\
\text { project }\end{array}$ \\
\hline $\begin{array}{l}\text { Wilson } \\
\text { (2019) [68] }\end{array}$ & $\begin{array}{c}\text { USA, University of } \\
\text { Denver Graduate School } \\
\text { of Social Work, Colorado } \\
\text { State University School } \\
\text { of Social Work }\end{array}$ & $\begin{array}{l}\text { Business, Computer } \\
\text { Science, Education, } \\
\text { Engineering, } \\
\text { International Studies, } \\
\text { Psychology, and Social } \\
\text { Work }\end{array}$ & $\begin{array}{l}\text { Interdisciplinary } \\
\text { team of faculty, } \\
\text { graduate students, } \\
\text { and community } \\
\text { member }\end{array}$ & $\begin{array}{l}\text { To encourage students } \\
\text { and community } \\
\text { members to come } \\
\text { together to brainstorm } \\
\text { to develop innovative } \\
\text { solutions to address } \\
\text { homelessness }\end{array}$ & $\begin{array}{l}\text { Design thinking } \\
\text { project } \\
\text { Presentations }\end{array}$ \\
\hline $\begin{array}{l}\text { Wobbe } \\
(2010)[69]\end{array}$ & $\begin{array}{c}\text { USA, Worcester } \\
\text { Polytechnic Institute }\end{array}$ & $\begin{array}{l}\text { Engineering and } \\
\text { Technology }\end{array}$ & First-year students & $\begin{array}{l}\text { To develop information } \\
\text { literacy, effective } \\
\text { writing, and speaking } \\
\text { skills, while working in } \\
\text { teams }\end{array}$ & $\begin{array}{l}\text { Design thinking } \\
\text { project }\end{array}$ \\
\hline $\begin{array}{l}\text { Wyrick } \\
(2016)[70]\end{array}$ & $\begin{array}{l}\text { USA, West Virginia } \\
\text { University, Statler } \\
\text { College of Engineering } \\
\text { and Mineral Resources }\end{array}$ & Civil Engineering & & $\begin{array}{l}\text { To develop a sense of } \\
\text { how to identify and act } \\
\text { on opportunity } \\
\text { To develop a } \\
\text { multicultural and } \\
\text { international } \\
\text { perspective to } \\
\text { comprehend the impact } \\
\text { of working with people } \\
\text { and society }\end{array}$ & $\begin{array}{l}\text { Design thinking } \\
\text { project }\end{array}$ \\
\hline
\end{tabular}


TABLE 3: Continued.

\begin{tabular}{|c|c|c|c|c|c|}
\hline $\begin{array}{l}\text { First author } \\
\text { (year) }\end{array}$ & Country and institution & Discipline & Students & $\begin{array}{c}\text { Course learning } \\
\text { objectives }\end{array}$ & Course assessments \\
\hline $\begin{array}{l}\text { Zou (2015) } \\
{[12]}\end{array}$ & $\begin{array}{l}\text { Hong Kong, China, } \\
\text { Center for Engineering } \\
\text { Education Innovation, } \\
\text { the Hong Kong } \\
\text { University of Science and } \\
\text { Technology }\end{array}$ & Engineering & $\begin{array}{l}\text { Freshmen from all } \\
\text { backgrounds }\end{array}$ & $\begin{array}{l}\text { To apply an integrated } \\
\text { learning approach to } \\
\text { learn about energy } \\
\text { To enhance critical } \\
\text { thinking and problem- } \\
\text { solving skills } \\
\text { To introduce a } \\
\text { multidisciplinary view } \\
\text { to understand energy } \\
\text { and its sensible usage } \\
\text { To introduce the } \\
\text { relationship between } \\
\text { energy and society } \\
\text { To tackle the } \\
\text { complexity of energy } \\
\text { through multiple } \\
\text { disciplines including } \\
\text { basic sciences, social } \\
\text { sciences, economics, } \\
\text { and technology }\end{array}$ & $\begin{array}{l}\text { Design thinking } \\
\text { project }\end{array}$ \\
\hline $\begin{array}{l}\text { Zuin (2019) } \\
\text { [71] }\end{array}$ & $\begin{array}{l}\text { BRA, Federal University } \\
\text { of Sao Carlos } \\
\text { GBR, University of York }\end{array}$ & Chemical Engineering & $\begin{array}{l}\text { First-year } \\
\text { undergraduate } \\
\text { students }\end{array}$ & $\begin{array}{l}\text { To develop a way to } \\
\text { extract valuable } \\
\text { products from orange } \\
\text { waste using chemistry } \\
\text { concepts and methods }\end{array}$ & $\begin{array}{l}\text { Design thinking } \\
\text { project }\end{array}$ \\
\hline
\end{tabular}

Note: countries are identified using the ISO alpha 3 codes.

The most common grand challenge topics were focused on sustainability, climate change, and food and water insecurity. This may be due to the wide variety of topics related to environmental sustainability including agriculture, soil, and land use to reducing global environmental footprints, biofuel use, and ecological restoration. As well, sustainability topics have increasingly multifaceted characteristics, as they encompass a wide range of sectors in society from government policies and economics to public health and security [28]. A variety of disciplines are able to participate in grand challenges centered on sustainability as they incorporate diverse issues on preserving the environment and supporting development in a society.

Despite the variety of disciplines identified as engaging in grand challenge work, many disciplines remain underrepresented in grand challenge literature to date. For instance, healthcare disciplines were present in some of the multidisciplinary groups involved in grand challenges; however, there was a distinct lack of literature that focused on grand challenges specific to healthcare disciplines, such as nursing. Additional grand challenges that target real-world societal issues might benefit disciplines that work consistently in teams and high-stress environments, such as those in healthcare professions. Disciplines such as political science that are involved in government policies may benefit from the implementation of additional grand challenges in higher education curricula, to build critical collaboration and problem-solving skills required in developing and changing public policies. Furthermore, many potential grand challenge topics were not discussed in the literature. For example, the education discipline could target interventions on bullying or information; communication and technology disciplines could strive to ensure the safe use of artificial intelligence in common technology.

Incorporation of interdisciplinary learning was commonly discussed as a course learning objective and in the research findings. As suggested by Ivanitskaya et al. [73], interdisciplinary learning can create knowledge that is "more holistic than knowledge built in discipline-specific studies" (p. 97). By incorporating interdisciplinary perspectives into the learning process, students can acquire knowledge about various methodologies, theories, paradigms, and concepts from multiple disciplines and evaluate their thinking processes against perspectives offered by different disciplines [73]. Furthermore, opportunities to engage in interdisciplinary problem-solving can help students explore and develop solutions in a synthesized manner while also building personal and professional skills [74].

Klaassen [75] evaluated the nature of interdisciplinary learning and factors to be considered when integrating interdisciplinary opportunities into the curricula. The choice of problem, level of interaction between different disciplines, and constructive alignment were identified as important variables to be considered. Designing group assignments that require collaborative and multidisciplinary research and developing problems and questions that are identified in conjunction with key stakeholders were identified imperative in promoting interdisciplinary learning [76, 77]. These 
TABLE 4: Grand challenge course assessments.

\begin{tabular}{|c|c|c|c|c|c|c|c|c|c|c|c|}
\hline $\begin{array}{l}\text { First author } \\
\text { (year) }\end{array}$ & $\begin{array}{c}\text { Active } \\
\text { discussions }\end{array}$ & $\begin{array}{l}\text { Design } \\
\text { thinking } \\
\text { projects }\end{array}$ & $\begin{array}{c}\text { Essays } \\
\text { or } \\
\text { reports }\end{array}$ & Infographics & $\begin{array}{l}\text { Learning } \\
\text { portfolio }\end{array}$ & $\begin{array}{c}\text { Oral } \\
\text { exams }\end{array}$ & $\begin{array}{c}\text { Peer } \\
\text { evaluation }\end{array}$ & Posters & Presentations & $\begin{array}{l}\text { Pre- } \\
\text { post } \\
\text { tests }\end{array}$ & Reflections \\
\hline $\begin{array}{l}\text { Apelian } \\
(2015)[26]\end{array}$ & $\mathbf{x}$ & $\mathbf{x}$ & $\mathbf{x}$ & & & & & $\mathbf{x}$ & $\mathbf{x}$ & & \\
\hline $\begin{array}{l}\text { Becerik- } \\
\text { Gerber } \\
(2018) \text { [27] }\end{array}$ & & $\mathbf{x}$ & & & & & & & & & \\
\hline $\begin{array}{l}\text { Berger } \\
(2013) \text { [28] }\end{array}$ & $\mathbf{x}$ & & & & & & & & $\mathbf{x}$ & $\mathbf{x}$ & $\mathbf{x}$ \\
\hline $\begin{array}{l}\text { Bernal } \\
(2013)\end{array}$ & & $\mathbf{x}$ & & & & $\mathbf{x}$ & $\mathbf{x}$ & & $\mathbf{x}$ & & \\
\hline $\begin{array}{l}\text { Brewer } \\
\text { (1993) [29] }\end{array}$ & $\mathbf{x}$ & $\mathbf{x}$ & & & & & & & $\mathbf{x}$ & & \\
\hline $\begin{array}{l}\text { Cohen } \\
(2010) \text { [30] }\end{array}$ & & $\mathbf{x}$ & & & & & & & $\mathbf{x}$ & & \\
\hline $\begin{array}{l}\text { Dean (2017) } \\
{[31]}\end{array}$ & & $\mathbf{x}$ & & & & & & $\mathbf{x}$ & & & \\
\hline $\begin{array}{l}\text { Flammia } \\
\text { (2011) [32] }\end{array}$ & & $\mathbf{x}$ & & & & & & & & & \\
\hline $\begin{array}{l}\text { Fomich } \\
(2018)[33]\end{array}$ & & $\mathbf{x}$ & $\mathbf{x}$ & & & & & & $\mathbf{x}$ & & \\
\hline $\begin{array}{l}\text { Forbes } \\
(2018) \text { [34] }\end{array}$ & $\mathbf{x}$ & & & $\mathbf{x}$ & & & & & $\mathbf{x}$ & & \\
\hline $\begin{array}{l}\text { Fortner } \\
(2016)[20]\end{array}$ & & & $\mathbf{x}$ & & & & & & & & \\
\hline $\begin{array}{l}\text { Fortuin } \\
\text { (2013) [35] }\end{array}$ & & $\mathbf{x}$ & $\mathbf{x}$ & & & & & & & & $\mathbf{x}$ \\
\hline $\begin{array}{l}\text { Gama (2018) } \\
{[36]}\end{array}$ & & $\mathbf{x}$ & & & & & & & & & \\
\hline $\begin{array}{l}\text { Gardner } \\
(2010) \text { [37] }\end{array}$ & & & $\mathbf{x}$ & & & & & $\mathbf{x}$ & $\mathbf{x}$ & & \\
\hline $\begin{array}{l}\text { Gillet (2019) } \\
{[38]}\end{array}$ & & $\mathbf{x}$ & & $\mathbf{x}$ & & & & & & & \\
\hline $\begin{array}{l}\text { Gosselin } \\
\text { (2016) [39] }\end{array}$ & & $\mathbf{x}$ & $\mathbf{x}$ & & & & & & & & \\
\hline $\begin{array}{l}\text { Griffin } \\
\text { (2011) [40] }\end{array}$ & & $\mathbf{x}$ & $\mathbf{x}$ & & & & $\mathbf{x}$ & & $\mathbf{x}$ & & $\mathbf{x}$ \\
\hline $\begin{array}{l}\text { Grose (2014) } \\
{[21]}\end{array}$ & & $\mathbf{x}$ & $\mathbf{x}$ & & & & & & $\mathbf{x}$ & & $\mathbf{x}$ \\
\hline $\begin{array}{l}\text { Hagfeldt } \\
\text { (2019) [41] }\end{array}$ & & $\mathbf{x}$ & & & & & & & $\mathbf{x}$ & & \\
\hline $\begin{array}{l}\text { Hasan } \\
(2017) \text { [42] }\end{array}$ & & $\mathbf{x}$ & & & & & & & & & \\
\hline $\begin{array}{l}\text { Hecht (2014) } \\
{[23]}\end{array}$ & & $\mathbf{x}$ & & & & & & & & & \\
\hline $\begin{array}{l}\text { Heinricher } \\
\text { (2008) [22] }\end{array}$ & $\mathbf{x}$ & $\mathbf{x}$ & $\mathbf{x}$ & & & & & & $\mathbf{x}$ & & \\
\hline $\begin{array}{l}\text { Holzer } \\
\text { (2016) [43] }\end{array}$ & & $\mathbf{x}$ & $\mathbf{x}$ & & & & & $\mathbf{x}$ & $\mathbf{x}$ & & $\mathbf{x}$ \\
\hline $\begin{array}{l}\text { Jahan (2019) } \\
{[44]}\end{array}$ & $\mathbf{x}$ & $\mathbf{x}$ & & & & & & & $\mathbf{x}$ & & \\
\hline $\begin{array}{l}\text { Johannes } \\
\text { (1996) [45] }\end{array}$ & & $\mathbf{x}$ & & & & & & & & & \\
\hline $\begin{array}{l}\text { Jonker } \\
\text { (2019) [46] }\end{array}$ & & $\mathbf{x}$ & & & $\mathbf{x}$ & & & & & & \\
\hline $\begin{array}{l}\text { Judge (2020) } \\
\text { [47] }\end{array}$ & & $\mathbf{x}$ & & & & & & & $\mathbf{x}$ & & \\
\hline $\begin{array}{l}\text { Kienzler } \\
\text { (2017) [24] }\end{array}$ & & & $\mathbf{x}$ & $\mathbf{x}$ & & & & $\mathbf{x}$ & $\mathbf{x}$ & & \\
\hline
\end{tabular}


TABle 4: Continued.

\begin{tabular}{|c|c|c|c|c|c|c|c|c|c|c|c|}
\hline $\begin{array}{l}\text { First author } \\
\text { (year) }\end{array}$ & $\begin{array}{c}\text { Active } \\
\text { discussions }\end{array}$ & $\begin{array}{l}\text { Design } \\
\text { thinking } \\
\text { projects }\end{array}$ & $\begin{array}{c}\text { Essays } \\
\text { or } \\
\text { reports }\end{array}$ & Infographics & $\begin{array}{l}\text { Learning } \\
\text { portfolio }\end{array}$ & $\begin{array}{c}\text { Oral } \\
\text { exams }\end{array}$ & $\begin{array}{c}\text { Peer } \\
\text { evaluation }\end{array}$ & Posters & Presentations & $\begin{array}{l}\text { Pre- } \\
\text { post } \\
\text { tests }\end{array}$ & Reflections \\
\hline $\begin{array}{l}\text { Kim (2018) } \\
{[48]}\end{array}$ & $\mathbf{x}$ & $\mathbf{x}$ & & & & & $\mathbf{x}$ & & $\mathbf{x}$ & & $\mathbf{x}$ \\
\hline $\begin{array}{l}\text { Knudson } \\
(2011)[49]\end{array}$ & & $\mathbf{x}$ & & & & & & & $\mathbf{x}$ & & \\
\hline $\begin{array}{l}\text { Leon (2015) } \\
{[50]}\end{array}$ & $\mathbf{x}$ & & $\mathbf{x}$ & & & & & & $\mathbf{x}$ & & \\
\hline $\operatorname{Lim}_{[51]}(2016)$ & & $\mathbf{x}$ & & & & & & & $\mathbf{x}$ & & \\
\hline $\begin{array}{l}\text { Nagarajan } \\
\text { (2019) [52] }\end{array}$ & & $\mathbf{x}$ & & & & & & & & & \\
\hline $\begin{array}{l}\text { Nicholas } \\
\text { (2019) [53] }\end{array}$ & & $\mathbf{x}$ & & & & & & & $\mathbf{x}$ & & \\
\hline $\begin{array}{l}\text { Nitkin } \\
\text { (2016) [54] }\end{array}$ & & $\mathbf{x}$ & & & & & & & $\mathbf{x}$ & & \\
\hline $\begin{array}{l}\text { Nurius } \\
\text { (2017) [55] }\end{array}$ & & $\mathbf{x}$ & & & & & & & & & \\
\hline $\begin{array}{l}\text { Piens (2015) } \\
{[56]}\end{array}$ & & $\mathbf{x}$ & & & & & & & & & \\
\hline $\begin{array}{l}\text { Radberg } \\
(2018) \text { [57] }\end{array}$ & & $\mathbf{x}$ & & & & & & & & & \\
\hline $\begin{array}{l}\text { Reichmanis } \\
\text { (2017) [58] }\end{array}$ & & $\mathbf{x}$ & & & & & & & & & \\
\hline Richards- & & & & & & & & & & & \\
\hline $\begin{array}{l}\text { Kortum } \\
\text { (2012) [59] }\end{array}$ & & $\mathbf{x}$ & & & & & & & $\mathbf{x}$ & & \\
\hline $\begin{array}{l}\text { Rodríguez } \\
\text { (2019) [60] }\end{array}$ & & $\mathbf{x}$ & & & & & & & & & \\
\hline $\begin{array}{l}\text { Sienko } \\
\text { (2013) [61] }\end{array}$ & $\mathbf{x}$ & $\mathbf{x}$ & & & & & & & & & \\
\hline $\begin{array}{l}\text { Tandon } \\
\text { (2017) [25] }\end{array}$ & & $\mathbf{x}$ & & & & & & & $\mathbf{x}$ & & \\
\hline $\begin{array}{l}\text { Telenko } \\
\text { (2016) [62] }\end{array}$ & & $\mathbf{x}$ & & & & & & & & & \\
\hline $\begin{array}{l}\text { Trowbridge } \\
\text { (2018) [63] }\end{array}$ & & $\mathbf{x}$ & & & $\mathbf{x}$ & & & & & & $\mathbf{x}$ \\
\hline $\begin{array}{l}\text { Udugama } \\
(2018)[64]\end{array}$ & & $\mathbf{x}$ & & & & & & & & & \\
\hline $\begin{array}{l}\text { White (2018) } \\
{[65]}\end{array}$ & $\mathbf{x}$ & & & & & & & & & & $\mathbf{x}$ \\
\hline $\begin{array}{l}\text { White (2017) } \\
\text { [66] }\end{array}$ & $\mathbf{x}$ & & $\mathbf{x}$ & & & & & & $\mathbf{x}$ & & \\
\hline $\begin{array}{l}\text { White (2014) } \\
\text { [67] }\end{array}$ & & $\mathbf{x}$ & & & & & & & & & \\
\hline $\begin{array}{l}\text { Wilson } \\
\text { (2019) [68] }\end{array}$ & & $\mathbf{x}$ & & & & & & & $\mathbf{x}$ & & \\
\hline $\begin{array}{l}\text { Wobbe } \\
\text { (2010) [69] }\end{array}$ & & $\mathbf{x}$ & & & & & & & & & \\
\hline $\begin{array}{l}\text { Wyrick } \\
\text { (2016) [70] }\end{array}$ & & $\mathbf{x}$ & & & & & & & & & \\
\hline $\begin{array}{l}\text { Zou (2015) } \\
{[12]}\end{array}$ & & $\mathbf{x}$ & & & & & & & & & \\
\hline $\begin{array}{l}\text { Zuin (2019) } \\
\text { [71] }\end{array}$ & & $\mathbf{x}$ & & & & & & & & & \\
\hline Total & 11 & 48 & 13 & 3 & 2 & 1 & 3 & 5 & 26 & 1 & 8 \\
\hline
\end{tabular}


TABLE 5: Overview of studies about the use of grand challenges in higher education courses.

\begin{tabular}{|c|c|c|c|c|}
\hline $\begin{array}{l}\text { First author } \\
\text { (year) }\end{array}$ & Study aims & Study design & Participants & Results \\
\hline $\begin{array}{l}\text { Berger (2013) } \\
{[28]}\end{array}$ & $\begin{array}{l}\text { To measure the extent } \\
\text { students increased their } \\
\text { content knowledge } \\
\text { To explore the extent students } \\
\text { felt they learned content } \\
\text { knowledge } \\
\text { To examine students' } \\
\text { opinions regarding gains } \\
\text { from participating in the } \\
\text { World Challenge course }\end{array}$ & $\begin{array}{l}\text { Multimethods case study } \\
\text { including pretest-posttests, } \\
\text { personal reflections, and } \\
\text { final debriefings }\end{array}$ & $\begin{array}{l}14 \text { students, } 6 \text { faculty } \\
\text { members, and } 4 \text { teaching } \\
\text { assistants from Biology, } \\
\text { Chemistry, Economics, } \\
\text { Education, English, } \\
\text { Management, Math, Public } \\
\text { Health, Nursing, Nutrition, } \\
\text { Physical Therapy, Political } \\
\text { Science, Social Work, and } \\
\text { Sociology }\end{array}$ & $\begin{array}{l}\text { Students } \\
\text { Statistically significant } \\
\text { difference in mean content } \\
\text { knowledge scores between } \\
\text { pretest and posttest } \\
\text { ( } p=0.000) \\
\text { Appreciated the team } \\
\text { collaboration, research } \\
\text { process, progress made, and } \\
\text { support from the faculty and } \\
\text { TAs } \\
9 \text { of } 14 \text { students strongly } \\
\text { agreed they were satisfied } \\
\text { with the course } \\
\text { All students strongly agreed } \\
\text { the classes stimulated to } \\
\text { intellectual engagement with } \\
\text { course material } \\
\text { Faculty } \\
\text { Strengths of the course were } \\
\text { student participation, } \\
\text { progress on proposing } \\
\text { innovative solutions, and } \\
\text { providing a rigorous and fun } \\
\text { learning environment } \\
\text { Most faculty were engaged } \\
\text { with and satisfied with the } \\
\text { course and plan to } \\
\text { incorporate more problem- } \\
\text { based, student-centered } \\
\text { learning into their courses }\end{array}$ \\
\hline
\end{tabular}


TABle 5: Continued.

\begin{tabular}{llll}
\hline $\begin{array}{l}\text { First author } \\
\text { (year) }\end{array}$ & Study aims & Study design & Participants \\
\hline
\end{tabular}

\section{Students}

A majority of students had positive responses to working in groups and working on the design thinking project

The grand challenge topic was described as interesting, enlightening, broad enough to tailor it to your interests, and brought up a relevant and pressing contemporary issue that should be taught on a university-wide scale

Students expressed an interest in having more knowledge about sustainability and

Multimethods case study including surveys of the students, subjective

Cohen (2010) To evaluate the success of the evaluation of the students' [30] Designing the Sustainable Foodshed course
25 undergraduate students from Design, Environmental Studies, and Liberal arts better preparation in design skills

Not surprisingly, the design students wanted more progress, and comments received by external reviewers about the students' interim and final products instruction in food systems while the liberal arts students felt deficient in design skills Faculty

Students were engaged in class throughout the semester, acquired a solid understanding of sustainability and food systems issues, and quickly learned how to integrate visual design techniques into their projects

Teaching as a team was rewarding and enriched the class, individual teaching abilities, and professional skills

Students favoured authentic, "real-life" projects and

To explore the potential for authentic, interdisciplinary,

Dean (2017)

[31] collaborative learning to enhance educational and social outcomes for health, architecture, and landscape architecture students
Qualitative study using focus groups for data collection and program/ project evaluation
15 nursing students, 10 architecture students, and 12 landscape students learned about feelings and attitudes as well as knowledge The interdisciplinary learning prepares students for the real world of work and collaboration offered valuable new perspectives, ideas, and knowledge 
TABle 5: Continued.

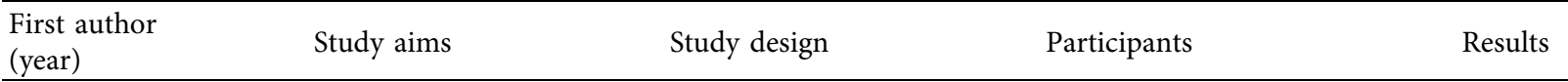
interactivity/hands-on,

To explore students perceived strengths and weaknesses of

Fortner (2016) [20] A Growing Concern: Sustaining Soil Resources Through Local Decision Making course
35 students across 3 institutions

Qualitative study: focus groups with students
Ecological sciences,

agriculture, geology, environmental sciences, and some nonscience majors
To identify the cognitive interdisciplinary skills that enhance students' ability to understand complex

Fortium (2013) [35] environmental problems and To explore how education in environmental systems analysis contribute to training these cognitive skills
Undergraduate students from a broad range of disciplines from Natural Sciences, Social

Sciences, Humanities, Technology, and Economics $2007(n=16)$ $2008(n=21)$ $2010(n=24)$ learned content, open-ended inquiry, quantifying the complex problems of erosion Students perceived the weaknesses of the course to be ambiguity of learning objectives, unclear structure, lack of personal relevance,

fast pace, and lack of concrete solutions

Students gained a more holistic understanding of environmental issues

Students explored systematic

vs. systemic approaches to environmental issues

Students gained skills in identifying, understanding, and appraising disciplinary knowledge

Students reflected on the role of science in solving environmental problems and learned by doing and through interaction

Quantitative analysis shows an agreement about the effectiveness of using design thinking

The strict time for intermediate deliveries in each step of the process

To identify what effects the combination of challengeGama (2018) based learning and design [36] thinking can have on hackathon projects
Mixed methods including 22 undergraduate Computer survey (quantitative data) Science students who were and group interviews (qualitative data) enrolled in the Web of Thing course helped to narrow down ideas and quickly find solutions to be developed Challenge-based learning helped guide students and give purpose to their projects, and guided them to learn more about the target domain and potential users

For some teams, the biggest challenge was that members dropped out part-way through, often due to scheduling conflicts or personal issues

The most effective ingredients for building strong teams were students' own efforts to step up and become leaders
Gillet (2019) and what could be improved [38] with the Michigan Initiative for Global Action Through Entrepreneurship
Qualitative study: class focus groups
Multidisciplinary undergraduate students 
TABle 5: Continued.

\begin{tabular}{llll}
\hline $\begin{array}{l}\text { First author } \\
\text { (year) }\end{array}$ & Study aims & Study design & Participants \\
\hline
\end{tabular}

Student assessments that helped bridge the disciplines were outside events, multidiscipline instructors,

To assess student learning

Gosselin

(2016) [39] related to course goals and student preferences related to course design and pedagogy
Mixed-methods case study: assignments, class discussions, team project, and student surveys
Interdisciplinary undergraduate students from

Science, Technology, Engineering, Math, and some from non-STEM disciplines problem-based learning, and project-based learning

The multidisciplinary course created challenges to

achieving the learning goals There was a need to incorporate greater systems thinking and fundamental knowledge into the next offering of the course

The course offered students a unique learning experience by developing their ability to actively apply their understanding of course concepts to formulate creative solutions to real political and social problems

An interdisciplinary program for engineering undergraduates including soft skills can increase students' perspective on societal issues as measured by the ESIT, especially when they show a positive attitude towards group work as measured by RIPLS and especially if they have a low ESIT at the start

To examine if an interdisciplinary program for Holzer (2016) engineering undergraduates [43] including soft skills can increase students' perspective

on societal issues
Pre-post tests

1800 first-year undergraduate Engineering students from 12 courses
A majority of students appreciated the course and almost $80 \%$ found the topic of their group work interesting.

Where students have a positive attitude towards group work at the beginning of the course, there are greater gains in postconventional reasoning during the course. This is especially true for students with the lowest levels of postconventional reasoning at the outset 
TABLE 5: Continued.

\begin{tabular}{|c|c|c|c|c|}
\hline $\begin{array}{l}\text { First author } \\
\text { (year) }\end{array}$ & Study aims & Study design & Participants & Results \\
\hline $\begin{array}{l}\text { Jahan (2019) } \\
\text { [44] }\end{array}$ & $\begin{array}{l}\text { To examine if students' } \\
\text { adaptive learning } \\
\text { engagement and perceived } \\
\text { confidence for learning } \\
\text { changes as a result of their } \\
\text { participation in } \\
\text { collaboratively taught design } \\
\text { thinking project course }\end{array}$ & $\begin{array}{l}\text { Mixed methods: pre-post } \\
\text { tests }(n=54) \text { and focus } \\
\text { groups }(n=9)\end{array}$ & $\begin{array}{l}54 \text { first-year undergraduate } \\
\text { Engineering students }\end{array}$ & $\begin{array}{l}\text { Students benefited from } \\
\text { working in a "real-world" } \\
\text { environment that required } \\
\text { them to figure out what } \\
\text { resources they needed to } \\
\text { solve a problem } \\
\text { Students expressed } \\
\text { confidence in their ability to } \\
\text { learn in the course } \\
\text { Self-Efficacy test "I can figure } \\
\text { out how to do difficult work" } \\
\text { ( } p=0.011) \\
\text { Self-Regulation test "I } \\
\text { continue working even if } \\
\text { there are better things to do" } \\
\text { ( } p=0.025) \text { "I concentrate so } \\
\text { that I will not miss important } \\
\text { points" ( } p=0.008) \text {, "I do not } \\
\text { give up even when the work is } \\
\text { difficult" ( } p=0.009) \text {, and "I } \\
\text { keep working until I finish } \\
\text { what I am supposed to do" } \\
\text { ( } p=0.004)\end{array}$ \\
\hline
\end{tabular}

Students experienced the course as a useful addition to their engineering education

The strong points of the course were freedom to define the problem, learning aspects of project-oriented work, teamwork, the multidisciplinary character

(learning from other

$\begin{array}{ll}\text { To explore students } \\ \text { Johannes } & \text { perceptions of an }\end{array}$

(1996) [45] interdisciplinary sustainable development course
Authors did not indicate Interdisciplinary Engineering how they collected data students disciplines), and the contact with an external principal Project work was less effective for pure knowledge transfer Contact with students from other departments and the different disciplinary aspects were noted as a positive learning experience, while stimulating interdisciplinary thinking and study 
TABle 5: Continued.

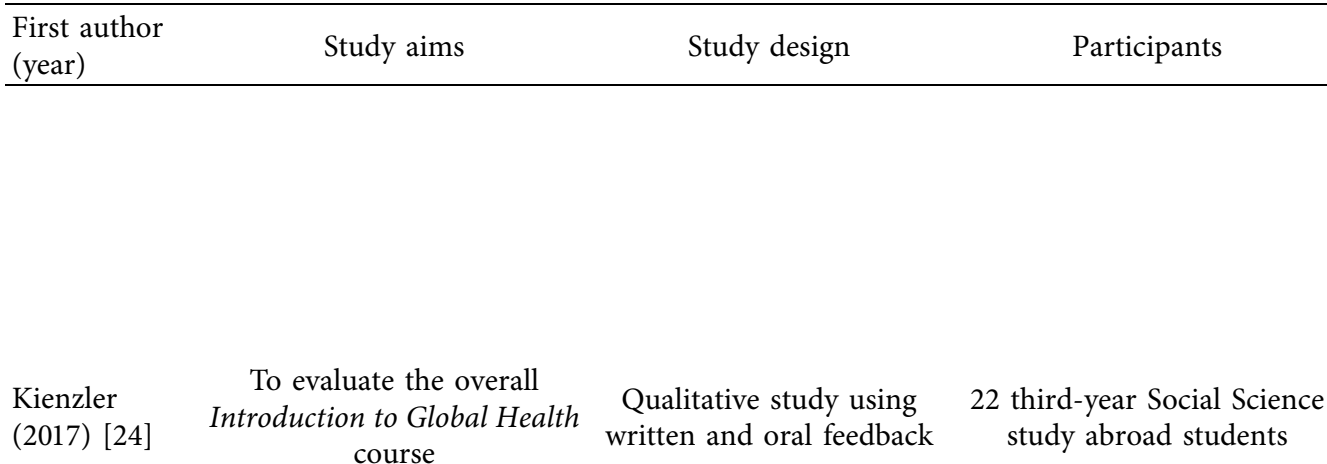

Kienzler
(2017) [24] course written and oral feedback
To explore students'

Lim (2016) perceptions of how problem-

[51] based learning contributes to

their understanding of

sustainability competencies
Qualitative case study

Masters students in Law, Natural, and Social Science

Midterm evaluations, completed by 21 students, indicated satisfaction with direct instructional guidance Students also indicated that they did not feel prepared for the hackathon and course assignments

Final evaluation, completed by 15 students, demonstrated ongoing satisfaction with the course content and had increased confidence in their ability to complete the course assignments

Students reported positive reactions to how the course content was delivered

Students found problembased learning challenging but appreciated the opportunity to "do something different"; to "engage with law in a way that makes a difference"; to "consider a wide range of issues at once" and to have a tool they could use in their future careers which would enable them to consider a wide range of options

Students consideration of cross-sectoral issues and legislative enforcement and effectiveness broadened their thinking about how different parts should interact and how this often fails to happen

$47 \%$ of respondents perceived the course activities to

To examine student feedback regarding the learning

Petillion (2019) [72] activities used in a course focused on addressing the United Nations Sustainability and course assignments
Mixed methods: surveys
357 first-year chemistry undergraduate students goals support their learning, with $30 \%$ believing otherwise and $22 \%$ responding neutrally to that statement suggesting that the course assignment had a positive impact on cognitive learning for a large number of students 
TABle 5: Continued.

\begin{tabular}{llll}
\hline $\begin{array}{l}\text { First author } \\
\text { (year) }\end{array}$ & Study aims & Study design & Participants
\end{tabular}
conducted their MSc thesis at the Challenge Lab was similar to students in general Intended learning outcomes Challenge Lab self-perceived learning fulfills the required academic learning outcomes

Radberg

(2018) [57]

for their education

To identify additional learning outcomes students perceive they have achieved, which are not developed to the same extent in traditional MSc thesis
To assess if students' in the
37 masters students in Engineering, multidisciplinary:

Mixed methods: surveys and interviews Physics, Technology Management, Civil Engineering, Energy, and Maritime Engineering
Environmental Studies,

(ILO's) measured on a 1-5

scale showed an average of 3.3 over all 3 years at the Challenge Lab, in line with all MSc thesis students studying at Chalmers in 2016 at 3.6 $(n=1765)$

The perceived learning about sustainable development was significantly higher for the

Challenge Lab students compared with the Chalmers students in general

Some students did not perceive that that had gained specialized knowledge within their main field of study

\begin{tabular}{|c|c|c|c|c|}
\hline $\begin{array}{l}\text { Richards- } \\
\text { Kortum } \\
\text { (2012) [59] }\end{array}$ & $\begin{array}{c}\text { To compare skills developed } \\
\text { through the Beyond } \\
\text { Traditional Borders course } \\
\text { with other design courses at } \\
\text { Rice }\end{array}$ & Survey & $\begin{array}{l}\text { Undergraduate Engineering } \\
\text { students }\end{array}$ & $\begin{array}{c}\text { Students reported enhanced } \\
\text { skills in creativity, leadership, } \\
\text { ability to effect social change, } \\
\text { and the ability to solve real- } \\
\text { world problems }\end{array}$ \\
\hline $\begin{array}{l}\text { Sienko (2013) } \\
\text { [61] }\end{array}$ & $\begin{array}{l}\text { To evaluate the educational } \\
\text { impact of the Design for } \\
\text { Global Health: Sustainable } \\
\text { Technologies for the } \\
\text { Developing World course on } \\
\text { students' perceived abilities } \\
\text { in specific engineering } \\
\text { design-related areas of } \\
\text { interest } \\
\text { To measure self-reported } \\
\text { professional progress in an } \\
\text { interdisciplinary } \\
\text { environment with a } \\
\text { nontraditional teaching } \\
\text { agenda } \\
\text { To explore students' } \\
\text { perceptions about teaching } \\
\text { methodology, general } \\
\text { direction of the course, and } \\
\text { the impacts on students' } \\
\text { academic and professional } \\
\text { growth }\end{array}$ & $\begin{array}{l}\text { Mixed methods: surveys } \\
\text { and focus groups }\end{array}$ & $\begin{array}{c}\text { Fifteen Engineering students } \\
\text { (one doctoral, } 12 \text { Masters and } \\
\text { two Bachelor's degrees) from } \\
\text { Mechanical Engineering } \\
\quad(n=9) \text {, Biomedical } \\
\text { Engineering }(n=5) \text {, and the } \\
\text { School of Information }(n=1)\end{array}$ & $\begin{array}{l}\text { Paired } t \text {-tests were completed } \\
\text { at the start and completion of } \\
\text { the course, with statistically } \\
\text { significant increases in } \\
\text { confidence for } 10 / 15 \\
\text { statements on the survey } \\
\text { related to design task } \\
\text { confidence } \\
\text { Focus group findings report } \\
\text { that the style of learning used } \\
\text { in the course was a factor } \\
\text { involved with increasing self- } \\
\text { confidence } \\
\text { Students also noted the } \\
\text { importance of learning } \\
\text { opportunities off-campus, } \\
\text { increasing ability to } \\
\text { contextualise needs } \\
\text { All students agreed that being } \\
\text { purpose-driven provided } \\
\text { motivation for active } \\
\text { engagement in the course }\end{array}$ \\
\hline
\end{tabular}


TABle 5: Continued.

\begin{tabular}{lllll}
\hline $\begin{array}{l}\text { First author } \\
\text { (year) }\end{array}$ & Study aims & Study design & Participants & Results \\
\hline
\end{tabular}

To examine changes in student interest and

Tandon knowledge about science and (2017) [25] engineering when engaged in solving the problem of disease with technology
Cross-sectional survey 60 Science and Engineering
Students had an overall increased interest in science and engineering after participating in the grand challenge

Questionnaire asked students to report self-interest in knowledge in Interest in Drones (Air) and (Land), Interest in Biotech Industry, Knowledge of Drones (Air) and (Land), and Knowledge of Biotech Industry.

Knowledge of drones (Air) $(p<0.001)$, Knowledge of Drones (land) $(p=0.001)$, Knowledge of Biotech Industry $(p<0.001)$ were significant

Students felt their knowledge increased significantly by participating in a grand challenge

All but one student stated that they would participate again in a grand challenge event if offered again

The mean responses of all 136 respondents identified significant increase in students' ability to engage successfully in design, foster cooperative team problemsolving skills, and increase interest in learning more about design with an average response of $4.3 / 5$ (95\% CI [0.13])
136 junior college Engineering students
To examine if the course and assignments encourage design, improve students' understanding of single

(2016) [62] subject material, and improve students' self-concept in integrating concepts from multiple disciplines of study through multidisciplinary problems
Surveys: postsurveys,

paired pre- and postsurveys, and paired pre- and postconcept quizzes
The students exhibited a modest understanding of concepts before the course and a stronger grasp after completing the design project There were no statistically significant shifts in students' perceived ability to solve thermodynamics problems 
TABle 5: Continued.

\begin{tabular}{|c|c|c|c|}
\hline $\begin{array}{l}\text { First author } \\
\text { (year) }\end{array}$ & Study aims & Study design & Participants \\
\hline $\begin{array}{l}\text { Trowbridge } \\
\text { (2018) [63] }\end{array}$ & $\begin{array}{l}\text { To understand how } \\
\text { participation in the Grand } \\
\text { Challenge Scholars Program } \\
\text { may influence first-year } \\
\text { engineering students' } \\
\text { development of a systems } \\
\text { perspective of engineering } \\
\text { To analyze how students } \\
\text { understand and describe the } \\
\text { relationship between society } \\
\text { and technology in their } \\
\text { reflections on their } \\
\text { experiences in an } \\
\text { interdisciplinary course }\end{array}$ & $\begin{array}{l}\text { Qualitative study analyzing } \\
\text { students written reflections }\end{array}$ & $\begin{array}{l}59 \text { first-year Engineering } \\
\text { students }\end{array}$ \\
\hline
\end{tabular}

Udugama

(2018) [64]
To evaluate the success of a real-world challenge for biotechnology students
Surveys

25 biotechnology graduate students
Results

Students recognized ways in which society influences technology and that technology has significant impacts on society

Students recognized the need for multiple disciplines, including but not limited to engineering, to be involved in developing successful solutions to grand challenges Several students recognized connections between areas of application, such as health, sustainability, and security, and described several

examples of challenges and solutions overlapping between themes

The student surveys indicated successful imparting technical and industrial knowledge to participants, while also providing a good balance between social and academic activities

$96 \%$ of respondents would highly recommend the course, data for the balance are only displayed in a bar graph and can only be estimated $\sim 80$

$\%$ strongly agree, $20 \%$ agree, and the $\sim 1 \%$ are neutral or disagree

Student's scores increased from 7.8 to 8.1 out of 10 , on the overall the Geoscience Literacy Exam (GSE) score One-half showed an improvement from the pretest to the posttest on individual GSE questions A higher percentage of students envisioned using what they learned in the course to help society overcome problems of environmental degradation, natural resources limitations, or other environmental issues 
To assess motivation for applying to the program; evaluation of the course structure, logistics, and content

White (2014)

[67]
To explore perspectives on and commitment to social justice

To self-assess professional skills, active engagement, confidence, and growth in seeking leadership and academic opportunities
Mixed methods: surveys and focus groups, pre-post tests
35 interdisciplinary undergraduate students
Survey results show that students felt highly engaged in the learning process Individual survey items indicated most or all students agreed or strongly agreed to items indicating a deep sense of engagement in selfdirected learning, and satisfaction with the structures supporting selfdirected learning 8 questions on engagement showed $100 \%$ of respondents agreed or strongly agreed, with the exception of "I received the support I needed to be successful in designing an actionable solution) in which $96.6 \%$ agreed/strongly agreed

All the students reported that they were active participants, they increased their knowledge and understanding of topics that interested them, and they enjoyed the intensity of immersing themselves in learning and project development

$100 \%$ of students agreed or strongly agreed that they see the world differently than they did before Students reflected that they see strengths in themselves that they did not previously see, and that they increased strengths they already had, becoming better versions of themselves. $100 \%$ of students agreed or strongly agreed with these statements Nearly $40 \%$ of students changed their study habits and two-thirds reflected a shift in how they participate in class as a result of this experience

More than $60 \%$ of respondents changed their behavior in regard to seeking leadership opportunities and engaging in community service

Nearly all current participants, and more than $85 \%$ of past participants, felt more integrated in their community 
TABLE 5: Continued.

\begin{tabular}{|c|c|c|c|c|}
\hline $\begin{array}{l}\text { First author } \\
\text { (year) }\end{array}$ & Study aims & Study design & Participants & Results \\
\hline $\begin{array}{l}\text { Wilson (2019) } \\
\text { [68] }\end{array}$ & $\begin{array}{l}\text { To explore student } \\
\text { perceptions of an } \\
\text { interdisciplinary course } \\
\text { about homelessness }\end{array}$ & $\begin{array}{l}\text { Mixed-methods case study } \\
\text { including survey data, pre- } \\
\text { and postevent surveys, } \\
\text { field observations, and } \\
\text { artifacts in the form of } \\
\text { team pitch presentations }\end{array}$ & $\begin{array}{c}32 \text { multidisciplinary } \\
\text { undergraduate and graduate } \\
\text { students }\end{array}$ & $\begin{array}{l}\text { Participants reported very } \\
\text { high levels of satisfaction on } \\
\text { their postcourse surveys } \\
\text { A strong majority of } \\
\text { participants (91\%) agreed or } \\
\text { strongly agreed that the } \\
\text { course met their expectations, } \\
\text { they gained something useful } \\
\text { from the course, they enjoyed } \\
\text { solving problems creatively, } \\
\text { and they enjoyed working as } \\
\text { an interdisciplinary team } \\
\text { A majority ( } 89 \%) \text { agreed or } \\
\text { strongly agreed that they } \\
\text { enjoyed learning about } \\
\text { homelessness } \\
\text { Paired } t \text {-test showed that self- } \\
\text { perceived knowledge } \\
\text { increased ( } p<0.01) \text {, change } \\
\text { in attitude towards: society } \\
\text { working collectively to } \\
\text { address homelessness } \\
\text { ( } p<0.01), \text { a contributing } \\
\text { factor to people experiencing } \\
\text { homelessness is failure of } \\
\text { social systems }(p<0.01) \text {, } \\
\text { participants should be } \\
\text { involved in social system } \\
\text { solutions }(p<0.01) \text {, and } \\
\text { increased students reported } \\
\text { participation in civic } \\
\text { engagement ( } p<0.001)\end{array}$ \\
\hline
\end{tabular}

may similarly be important considerations for those seeking to create multidisciplinary grand challenge courses.

The promotion of critical thinking to develop a better understanding of societal problems was identified as a common learning objective in the grand challenge literature. As noted in our findings, critical thinking can facilitate thoughtful evaluation and strategic planning to develop innovative solutions to grand challenges. Walker [78] suggests questioning, classroom discussions, debates, and written assignments to be some of the best methods to promote critical thinking. Further, Hofreiter et al. [79] have suggested the use of real-world examples, such as societal grand challenges, as preeminent in promoting critical thinking skills.

The most common course assessments were design thinking projects. Design thinking is a process that is analytic and creative which "engages individuals in opportunities to experiment, create and prototype models, gather feedback, and redesign" [80]; p. 330). Foshay and Kirkley [81] suggest the use of authentic problems, such as grand challenges, in conjunction with practice and assessments, as seen in design thinking assignments, to promote the development of problem-solving skills. Glen et al. [82] suggest that design thinking facilitates rapid learning, builds confidence in working with complex problems, and provides tools to develop diverse perspectives. In addition to helping build confidence, design thinking promotes the development of transferable professional skills including communication, integrative thinking, innovation, and collaboration [83].

Professional and personal skills development was identified as another common course objective and research finding. Singh and Gera [84] discussed the importance of skills development in higher education curricula and suggested the incorporation of collaborative pedagogy techniques and activities such as project work, practical learning, and group presentations to increase broader skill development. Nordstrom and Korpelainen [85] suggested creating videos, posters, and models, all of which are common to grand challenge courses, to help further enhance important professional and personal skills. Similar to design thinking projects, presentations, essays, and active discussions also promote the growth of transferable professional skills. Student presentations and active discussions help build the skills of verbal communication, active listening, networking, and time management, while written essays and reports promote the development of written communication, analytical skills, and professional language [84].

5.1. Gaps in Evidence and Suggestions for Future Research. Research regarding the incorporation of grand challenges in higher education is still in its early stages. The impact of the design and delivery of grand challenge courses in higher 
education remains an underexplored area of research. To date, there are few comparative research designs and no experimental, quasiexperimental, or longitudinal research. Additional comparative studies are needed to identify effective approaches to design, embed, and promote the use of grand challenges as a pedagogical approach. Future research should also explore the involvement of females compared to males in grand challenges and how to promote equitable involvement of students in the minority.

5.2. Strengths and Limitations. Although a robust and systematic method was used to identify all published literature on grand challenges in higher education, we cannot rule out the possibility that our search missed some relevant sources. Contacting grand challenge experts may have helped identify more grey literature to include in our review. A majority of the included studies were from the US. While this reflects the current state of evidence on grand challenge use in higher education, the disproportionate geographical representation may not accurately reflect grand challenge use in other higher education institutions from other countries.

The limited depth to which grand challenges have been empirically explored reduced our ability to make strong conclusive statements about grand challenge outcomes. Due to the heterogeneity of current grand challenge literature, no systematic review of grand challenge studies is possible at this time. In general, studies examining grand challenge use in higher education are weak in their methodological rigor and did not adequately explain their data analysis procedures, making it difficult to conclude that, based on these studies, grand challenge initiatives were successful in meeting their intended outcomes. Despite these limitations, the findings from this scoping review reflect the current state of evidence for the use of grand challenges in higher education while underscoring the need for additional research with robust study designs to better understand the impact and outcomes of grand challenge work.

\section{Conclusion}

This scoping review helped further our understanding of the use of grand challenges in higher education. While there are clear benefits to incorporating grand challenges into higher education curricula, future research is needed to determine how instructors and institutions can best incorporate grand challenge teaching and learning opportunities. In identifying what is known as well as gaps in the existing literature, this review helps further the development of, and ongoing improvements to, grand challenges in the context of higher education.

\section{Data Availability}

The data used to support the findings of this scoping review study are included within the article.

\section{Disclosure}

The corresponding author completed JBI Comprehensive Systematic Review Training at the Queens Collaboration for Healthcare Quality: a JBI Center of Excellence.

\section{Conflicts of Interest}

The authors have no conflicts of interest to declare.

\section{Acknowledgments}

This review was funded in part by a Western and Northern Region of the Canadian Schools of Nursing Education Innovation Grant. The Program for Undergraduate Research Experience (PURE) provided financial support for two University of Calgary undergraduates to help conduct this review.

\section{References}

[1] G. George, J. Howard-Grenville, A. Joshi, and L. Tihanyi, "Understanding and tackling societal grand challenges through management research," Academy of Management Journal, vol. 59, no. 6, pp. 1880-1895, 2016.

[2] F. Ferraro, D. Etzion, and J. Gehman, "Tackling grand challenges pragmatically: robust action revisited," Organization Studies, vol. 36, no. 3, pp. 363-390, 2015.

[3] C. Cagnin, E. Amanatidou, and M. Keenan, "Orienting European innovation systems towards grand challenges and the roles that FTA can play," Science and Public Policy, vol. 39, no. 2, pp. 140-152, 2012.

[4] C. Wojciech, "Grand challenges: a way out of the ivory tower for management academic discipline," Management Issues, vol. 4, no. 84, pp. 9-23, 2019.

[5] J. H. Kwakkel and E. Pruyt, "Using system dynamics for grand challenges: the EDMA approach," Systems Research and Behavioral Science, vol. 32, no. 3, pp. 358-375, 2015.

[6] K. M. Eisenhardt, M. E. Graebner, and S. Sonenshein, "Grand challenges and inductive methods: rigor without rigor mortis," Academy of Management Journal, vol. 59, no. 4, pp. 1113-1123, 2016.

[7] K. Schwenk, D. K. Padilla, G. S. Bakken, and R. J. Full, "Grand challenges in organismal biology," Integrative and Comparative Biology, vol. 49, no. 1, pp. 7-14, 2009.

[8] L. Zimdars, "The worlds of cross-functional teams," in Crossfunctional Teams: Working with Aliens, Enemies, and Other Strangers, G. M. Parker, Ed., pp. 1-11, Jossey-Bass, San Francisco, CA, USA, 2003.

[9] J. Kania and M. Kramer, "Collective impact," Stanford Social Innovation Review, vol. 9, no. 1, pp. 36-42, 2011.

[10] C. M. Vest, "Context and challenge for twenty-first century engineering education," Journal of Engineering Education, vol. 97, no. 3, pp. 235-236, 2008.

[11] D. Jonassen, J. Strobel, and C. B. Lee, "Everyday problem solving in engineering: lessons for engineering educators," Journal of Engineering Education, vol. 95, no. 2, pp. 139-151, 2006.

[12] T. X. P. Zou and N. C. Mickleborough, "Promoting collaborative problem-solving skills in a course on engineering grand challenges," Innovations in Education and Teaching International, vol. 52, no. 2, pp. 148-159, 2015. 
[13] R. Bass, "Disrupting ourselves: the problem of learning in higher education," EDUCAUSE Review, vol. 47, no. 2, pp. 114, 2012.

[14] G. D. Kuh, "High-impact educational practices: what they are, who has access to them, and why they matter," Peer Review, vol. 14, no. 3, p. 29, 2008.

[15] J. Roberts, "From the editor: the possibilities and limitations of experiential learning research in higher education," Journal of Experiential Education, vol. 41, no. 1, pp. 3-7, 2018.

[16] S. A. Ambrose, M. W. Bridges, M. DiPietro, M. C. Lovett, and M. K. Norman, How Learning Works: Seven Research-Based Principles for Smart Teaching, Jossey-Bass, San Francisco, CA, USA, 1st edition, 2010.

[17] A. Y. Kolb and D. A. Kolb, “The learning way," Simulation \& Gaming, vol. 40, no. 3, pp. 297-327, 2009.

[18] M. D. J. Peters, C. Godfrey, P. McInerney, Z. Munn, A. C. Tricco, and H. Khalil, "Chapter 11: scoping reviews," in JBI Manual For Evidence Synthesis (2020 Version), E. Aromataris and Z. Munn, Eds., JBI, Adelaide, Australia, 2020, https://wiki.joannabriggs.org/display/MANUAL/ Chapter+11\%3A+Scoping+reviews.

[19] A. C. Tricco, E. Lillie, W. Zarin et al., "Extension for scoping reviews (PRISMA-ScR): checklist and explanation," Annals of Internal Medicine, vol. 37, no. 7, pp. 467-473, 2018.

[20] S. K. Macdonald, H. H. Scherer, and M. A. Murphy, "Engaging undergraduates in soil sustainability decision-making through an InTeGrate module," Journal of Geoscience Education, vol. 64, no. 4, pp. 259-269, 2016.

[21] T. K. Grose, "Millennial Magnet," PRISM ASEE, http://www. asee-prism.org/millennial-magnet-oct/, 2014.

[22] A. Heinricher, B. Savilonis, D. Spanagel, R. Traver, and K. Wobbe, "Great problems seminars: a new first-year foundation at WPI," in Proceedings of the ASEE Regional Meeting, West Point, NY, USA, 2008, https://digitalcommons. wpi.edu/gps-research/1/.

[23] B. A. Hecht, T. T. Jouttenus, M. J. Jouttenus et al., "The KumbhThon Technical Hackathon for Nashik: A Model for STEM Education and Social Entrepreneurship," in Proceedings of the 2014 IEEE Integrated STEM Education Conference, Princeton, NJ, USA, March 2014.

[24] H. Kienzler and C. Fontanesi, "Learning through inquiry: a global health hackathon," Teaching in Higher Education, vol. 22, no. 2, pp. 129-142, 2017.

[25] J. Tandon, R. Akhavian, M. Gumina, and N. Pakpour, "CSU East Bay hack day: a University Hackathon to Combat Malaria and Zika with drones," in Proceedings of the 2017 IEEE Global Engineering Education Conference (EDUCON), Athens, Greece, April 2017.

[26] D. Apelian, "Empowering first year students by immersion in a "Grand Challenges" course on sustainable development," Journal of the Mineral, Metals and Materials Society, vol. 62, no. 4, pp. 8-9, 2015.

[27] B. Becerik-Gerber, D. Druhora, D. Gerber, and B. Cracchiola, "Engineering innovation for global challenges: peacebuilding in refugee camps: creating innovators and witnesses," in Proceedings of the World Engineering Education Forum-Global Engineering Deans Council (WEEF-GEDC), Albuquerque, NM, USA, November 2018.

[28] M. Berger, E. Scott, J. B. Axe, and I. W. Hawkins, "World challenge: engage sophomores in an intensive, interdisciplinary course," International Journal of Teaching and Learning in Higher Education, vol. 25, no. 3, pp. 333-345, 2013.
[29] C. A. Brewer and J. M. Beiswenger, "Carbon dioxide \& the greenhouse effect: a problem evaluation activity," The American Biology Teacher, vol. 55, no. 4, pp. 238-240, 1993.

[30] N. Cohen, "Designing the sustainable foodshed: a crossdisciplinary undergraduate environmental studies course," Innovative Higher Education, vol. 35, no. 1, pp. 51-60, 2010.

[31] S. Dean, C. Williams, S. Donnelly, and T. Levett-Jones, "Designing a women's refuge: an interdisciplinary health, architecture and landscape collaboration," International Journal of Higher Education, vol. 6, no. 6, pp. 139-148, 2017.

[32] M. Flammia and H. A. Sadri, "Intercultural communication from an interdisciplinary perspective," US-China Education Review, vol. 8, no. 1, pp. 103-109, 2011.

[33] A. Fomich, P. Sours, and G. D. Bixler, "An innovative approach to teaching appropriate technology for developing countries," International Journal for Service Learning in Engineering, Humanitarian Engineering and Social Entrepreneurship, vol. 13, no. 2, pp. 10-24, 2018.

[34] C. T. Forbes, N. Brozović, T. E. Franz, D. E. Lally, and D. N. Petitt, "Water in society: an interdisciplinary course to support undergraduate students' water literacy," Journal of College Science Teaching, vol. 48, no. 1, pp. 36-42, 2018.

[35] K. P. J. Fortuin, C. S. A. van Koppen, and C. Kroeze, "The contribution of systems analysis to training students in cognitive interdisciplinary skills in environmental science education," Journal of Environmental Studies and Sciences, vol. 3, no. 2, pp. 139-152, 2013.

[36] K. Gama, B. Alencar, F. Calegario, A. Neves, and P. Alessio, "A hackathon methodology for undergraduate course projects," in Proceedings of the IEEE Frontiers in Education Conference (FIE), San Jose, CA, USA, October 2018.

[37] D. S. Gardner, E. Tuchman, and R. Hawkins, "A cross-curricular, problem-based project to promote understanding of poverty in urban communities," Journal of Social Work Education, vol. 46, no. 1, pp. 147-156, 2010.

[38] A. Gillet, "Global, experiential- and virtual," Biz Ed, pp. 36-41, 2019, https://bized.aacsb.edu/articles/2019/july/globalexperiential-and-virtual.

[39] D. Gosselin, S. Burian, T. Lutz, and J. Maxson, "Integrating geoscience into undergraduate education about environment, society, and sustainability using place-based learning: three examples," Journal of Environmental Studies and Sciences, vol. 6, no. 3, pp. 531-540, 2016.

[40] D. Griffin, "Nudging students' creative problem-solving skills," PS: Political Science \& Politics, vol. 44, no. 02, pp. 425-427, 2011.

[41] A.-K. Högfeldt, A. Rosén, C. Mwase et al., "Mutual capacity building through north-south collaboration using challengedriven education," Sustainability, vol. 11, no. 24, p. 7236, 2019.

[42] H. Hasan and C. Ionescu, "Co-development of a wiki for tracking the environmental footprint of small business activities," Informing Science: The International Journal of an Emerging Transdiscipline, vol. 20, pp. 237-258, 2017.

[43] A. Holzer, I. V. Cardia, S. Bendahan et al., "Increasing the perspectives of engineering undergraduates on societal issues through an interdisciplinary program," International Journal of Engineering Education, vol. 32, no. 2, pp. 614-624, 2016.

[44] K. Jahan, C. A. Bodnar, S. Farrell et al., "Improving students' learning behaviors through hands-on algae based project," The International Journal of Engineering Education, vol. 35, no. 5, pp. 1343-1352, 2019.

[45] M. N. Johannes and V. Kasteren, "Interdisciplinary teaching within engineering education," European Journal of Engineering Education, vol. 21, no. 4, pp. 387-392, 1996. 
[46] J. Jonker and N. Faber, "Insights from teaching sustainable business models using a Mooc and a hackathon," Journal of Business Models, vol. 7, no. 3, pp. 57-66, 2019.

[47] P. K. Judge, J. A. Buxton, T. C. Sheahan, E. R. Phetteplace, D. L. Kriebel, and E. M. H. Infield, "Teaching across disciplines: a case study of a project-based short course to teach holistic coastal adaptation design," Journal of Environmental Studies and Sciences, vol. 10, pp. 341-351, 2020.

[48] E. Kim, C. Newman, M. Lastova, T. Bosman, and G. J. Strimel, "Engineering the reduction of food waste: teaching problem framing and project management through culturally situated learning," Technology and Engineering Teacher, vol. 78, no. 3, pp. 27-33, 2018.

[49] K. M. Knudson, J. Gutstein, and E. R. Evans, "A model of public scholarship that integrates professional skills into graduate education," Journal of Public Scholarship in Higher Education, vol. 1, pp. 109-131, 2011.

[50] J. S. Leon, K. Winskell, D. A. McFarland, and C. D. Rio, “A case-based, problem-based learning approach to prepare master of public health candidates for the complexities of global health," American Journal of Public Health, vol. 105, no. S1, pp. S92-S96, 2015.

[51] M. Lim and A. Allan, "The use of scenarios in legal education to develop futures thinking and sustainability competencies," The Law Teacher, vol. 50, no. 3, pp. 321-340, 2016.

[52] S. Nagarajan and T. Overton, "Promoting systems thinking using project- and problem-based learning," Journal of Chemical Education, vol. 96, no. 12, pp. 2901-2909, 2019.

[53] T. J. Nichols, B. Larson, S. Stluka, N. Van Heek, and R. C. Bott-Knutson, "Collaborative, holistic, honors approach to meeting agriculture's grand challenges," NACTA Journal, vol. 63, no. 2, pp. 282-287, 2019.

[54] M. R. Nitkin, S. K. White, and M. Shapiro, "Professional skills as cornerstones of liberal education: moving students from theory to action," College Teaching, vol. 64, no. 1, pp. 10-18, 2016.

[55] P. S. Nurius, D. S. Coffey, R. Fong, W. S. Korr, and R. McRoy, "Preparing professional degree students to tackle grand challenges: a framework for aligning social work curricula," Journal of the Society for Social Work and Research, vol. 8, no. 1, pp. 99-118, 2017.

[56] K. M. Piens, A. L. Schultz, R. G. Tanaka, J. L. Atzinger, and C. N. H. Miannan, "Engineering relief for Haiti," IEEE Potentials, vol. 34, no. 1, pp. 6-10, 2015.

[57] K. K. Radberg, U. Lundqvist, J. Malmqvist, and O. H. Svensson, "From CDIO to challenge-based learning experiences-expanding student learning as well as societal impact?" European Journal of Engineering Education, vol. 45, no. 1, pp. 22-37, 2018.

[58] E. Reichmanis and M. Sabahi, "Life cycle inventory assessment as a sustainable chemistry and engineering education tool," ACS Sustainable Chemistry \& Engineering, vol. 5, no. 11, pp. 9603-9613, 2017.

[59] R. Richards-Kortum, L. V. Gray, and M. Oden, "Engaging undergraduates in global health technology innovation," Science, vol. 336, no. 6080, pp. 430-431, 2012.

[60] L. F. Rodríguez, A. M. Marshall, D. Cotton et al., "The development of the INFEWS-ER: a virtual resource center for transdisciplinary graduate student training at the nexus of food, energy, and water," Frontiers in Environmental Science, vol. 7, no. 38, 2019.

[61] K. H. Sienko, A. S. Sarvestani, and L. Grafman, "Medical device compendium for the developing world: a new approach in project and service-based learning for engineering graduate students," Global Journal of Engineering Education, vol. 15, no. 1, pp. 13-20, 2013.

[62] C. Telenko, K. Wood, K. Otto et al., "Designettes: an approach to multidisciplinary engineering design education," Journal of Mechanical Design, vol. 138, no. 2, 2016.

[63] A. Trowbridge, H. Zhu, and J. Collofello, "First year students developing a systems perspective in the grand challenge scholars program," in Proceedings of the World Engineering Education Forum-Global Engineering Deans Council (WEEFGEDC), Albuquerque, NM, USA, November 2018.

[64] I. A. Udugama, H. Feldman, S. C. de las Heras et al., "BIOPRO World Talent Campus: a week of real world challenge for biotechnology post-graduate students," Education for Chemical Engineers, vol. 25, pp. 1-8, 2018.

[65] C. K. White, "Taking HEED within the context of peace education: grand challenges scholars program's curricular focus for peace," in Proceedings of the World Engineering Education Forum-Global Engineering Deans Council (WEEFGEDC), Albuquerque, NM, USA, November 2018.

[66] T. White, A. Wymore, A. Dere, A. Hoffman, J. Washburne, and M. Conklin, "Integrated interdisciplinary science of the critical zone as a foundational curriculum for addressing issues of environmental sustainability," Journal of Geoscience Education, vol. 65, no. 2, pp. 136-145, 2017.

[67] S. K. White and M. R. Nitkin, "Creating a transformational learning experience: immersing students in an intensive interdisciplinary learning environment," International Journal for the Scholarship of Teaching and Learning, vol. 8, no. 2, 2014.

[68] J. Wilson, K. Bender, and J. DeChants, "Beyond the classroom: the impact of a university-based civic hackathon addressing homelessness," Journal of Social Work Education, vol. 55, no. 4, pp. 736-749, 2019.

[69] K. Wobbe and A. Heinricher, "Mini workshop-great problems lead to great projects: a first year seminar course," in Proceedings of the IEEE Frontiers in Education Conference (FIE), Washington, DC, USA, October 2010.

[70] D. A. Wyrick and W. Myers, "Strategic project management to use the grand challenge scholars program to address urban infrastructure," Frontiers of Engineering Management, vol. 3, no. 3, pp. 203-205, 2016.

[71] V. G. Zuin, M. L. Segatto, D. P. Zandonai et al., "Integrating green and sustainable chemistry into undergraduate teaching laboratories: closing and assessing the loop on the basis of a citrus biorefinery approach for the biocircular economy in Brazil," Journal of Chemical Education, vol. 96, no. 12, pp. 2975-2983, 2019.

[72] R. J. Petillion, T. K. Freeman, and W. S. McNeil, "United nations sustainable development goals as a thematic framework for an introductory chemistry curriculum," Journal of Chemical Education, vol. 96, no. 12, pp. 2845-2851, 2019.

[73] L. Ivanitskaya, D. Clark, G. Montgomery, and R. Primeau, "Interdisciplinary learning: processes and outcomes," Innovative Higher Education, vol. 27, no. 2, pp. 95-111, 2002.

[74] C. Jones, "Interdisciplinary approach - advantages, disadvantages, and the future benefits of interdisciplinary studies," ESSAI, vol. 7, no. 26, pp. 76-81, 2009.

[75] R. G. Klaassen, "Interdisciplinary education: a case study," European Journal of Engineering Education, vol. 43, no. 6, pp. 842-859, 2018.

[76] K. Francis, M. Henderson, E. Martin, K. Saul, and S. Joshi, "Collaborative teaching and interdisciplinary learning in graduate environmental studies," Journal of Environmental Studies and Sciences, vol. 8, no. 3, pp. 343-350, 2018. 
[77] K. Scager, F. A. C. Wiegant, J. Boonstra, A. J. M. Peeters, and J. P. Vulperhorst, "Collaborative learning in higher education: evoking positive interdependence," CBE Life Sciences Education, vol. 15, no. 4, 2016.

[78] S. Walker, "Active learning strategies to promote critical thinking," Journal of Athletic Training, vol. 38, no. 3, pp. 263-267, 2003.

[79] T. D. Hofreiter, M. C. Monroe, and T. V. Stein, "Teaching and evaluating critical thinking in an environmental context," Applied Environmental Education \& Communication, vol. 6, no. 2, pp. 149-157, 2007.

[80] R. Razzouk and V. Shute, "What is design thinking and why is it important?" Review of Educational Research, vol. 82, no. 3, pp. 330-348, 2012.

[81] R. W. Foshay and J. Kirkley, "Principles for teaching problem solving (technical paper \#4)," PLATO, https://files.eric.ed.gov/ fulltext/ED464604.pdf, 1998.

[82] R. Glen, C. Suciu, C. C. Baughn, and R. Anson, "Teaching design thinking in business schools," The International Journal of Management Education, vol. 13, no. 2, pp. 182-192, 2015.

[83] J. Benson and S. Dresdow, "Design for thinking: engagement in an innovation project," Decision Sciences Journal of Innovative Education, vol. 13, no. 3, pp. 377-410, 2015.

[84] H. Singh and M. Gera, "Developing generic skills in higher education," Indian Journal of Applied Research, vol. 5, no. 6, pp. 824-826, 2015.

[85] K. Nordstrom and P. Korpelainen, "Creativity and inspiration for problem solving in engineering education," Teaching in Higher Education, vol. 16, no. 4, pp. 439-450, 2011. 